OPEN ACCESS

Citation: Wong Sin Yeng, Peter C. Boyce (2021) Studies on Schismatoglottideae (Araceae) of Borneo LXX - New colonial species for the Schismatoglottis [Calyptrata Clade] from Sarawak. Webbia. Journal of Plant Taxonomy and Geography 76(2): 221-243. doi: 10.36253/jopt-10798

Received: April 14, 2021

Accepted: June 2, 2021

Published: September 7, 2021

Copyright: @2021 Wong Sin Yeng, Peter C. Boyce. This is an open access, peer-reviewed article published by Firenze University Press (http://www. fupress.com/webbia) and distributed under the terms of the Creative Commons Attribution License, which permits unrestricted use, distribution, and reproduction in any medium, provided the original author and source are credited.

Data Availability Statement: All relevant data are within the paper and its Supporting Information files.

Competing Interests: The Author(s) declare(s) no conflict of interest.

Editor: David Scheberich

ORCID

WSY: https://orcid.org/0000-0003-40429672

PCB: https://orcid.org/0000-0002-58569561

\section{Studies on Schismatoglottideae (Araceae) of Borneo LXX - New colonial species for the Schismatoglottis [Calyptrata Clade] from Sarawak}

\author{
Wong Sin Yeng ${ }^{1,2,3, *}$, Peter C. Boyce 3 \\ ${ }^{1}$ Institute of Biodiversity and Environmental Conservation, Universiti Malaysia Sarawak \\ 94300 Kota Samarahan, Sarawak, Malaysia \\ ${ }^{2}$ Harvard University Herbaria, 22 Divinity Avenue, Cambridge, MA 02138, USA \\ ${ }^{3}$ Department Biologie I, Systematische Botanik und Mykologie, Ludwig-Maximilians- \\ Universität München, München, Germany \\ ${ }^{*}$ Corresponding author. E-mail: sywong@unimas.my
}

\begin{abstract}
Three new colonial species of Schismatoglottis Calyptrata clade are described and illustrated from Sarawak and compared with the four pre-existing morphologically similar species occurring in the state. A modified description of Schismatoglottis niahensis is provided to correct a previous misinterpretation of the stem architecture. All seven recognized species are illustrated from living plants.
\end{abstract}

Keywords: Araceae, Schismatoglottis, Calyptrata clade, Sarawak, Borneo.

\section{INTRODUCTION}

Previous comprehensive regional accounts for Schismatoglottis (Hay 1996; Hay and Yuzammi 2000) provided an excellent baseline to undertake further study. Preliminary work on the Schismatoglottis Calyptrata clade for Sarawak (Wong 2012; Wong et al. 2016) recognized six species, four of which are stolonifeous-colonial, and of which Schismatoglottis baangongensis S.Y.Wong, Y.C.Hoe \& P.C.Boyce (Wong et al. 2016: 80) was newly described and S. muluensis M. Hotta (Hotta 1966: 235) resurrected from within S. calyptrata Zoll. \& Moritzi (Moritzi 1846: 83), with the latter treated as absent from Sarawak, and with its occurrence on Borneo considered to be doubtful.

Subsequently (Wong et al. 2018; Wong \& Boyce 2020a) defined S. calyptrata as restricted to Maluku (the Type is from Pulau Ambon) through the Philippines archipelago and possibly occurring as far north as Lanyu Do (Taiwan) [but see Schismatoglottis kotoensis (Hayata) T.C.Huang, J.L.Hsiao \& H.Y.Ye (Huang et al. 2000: 305)], eastwards through New Guinea and the Bismarck Archipelago to the Solomons. Determining to what extent Schismatoglottis calyptrata sensu strictiore occurs in the eastern part of this area still 
requires much work (see Hay in Hay \& Yuzammi 2000; Wong et al. 2018). Implementing narrower species definitions means that plants formerly treated as $S$. calyptrata in Sarawak are new species that require publication for Borneo. In many instances the material to hand is inadequate to allow publication at the present time. This paper deals with three novelties for which we have complete material.

As noted in previous papers (e.g., Hay 1998; Boyce \& Wong 2015; Kartini et al. 2015; Wong \& Boyce 2020b) the extraordinarily complex surface geology of the island of Borneo is enormously important in the separation of species in aroid genera such as Homalomena, Schismatoglottis, and Alocasia, among others. Geology in this paper is specified based on Hutchison $(1989,2005)$ and Tate (2001).

1. Schismatoglottis adducta S.Y.Wong \& P.C.Boyce, sp. nov.

Type: Malaysian Borneo. Sarawak: Sri Aman Division, Tempat Rekreasi Sungai Raya, banks of the Sungai Raya, $1^{\circ} 06^{\prime} 49.2^{\prime \prime} \mathrm{N} 111^{\circ} 30^{\prime} 56.8^{\prime \prime} \mathrm{E}, 86 \mathrm{~m}$ asl., 9 Dec 2005, P.C.Boyce, Jeland ak Kisai, Jepom ak Tisai \& Mael ak Late AR-1632 (holotype SAR!). (Figures 1, 2 and 14A).

\section{Diagnosis}

Schismatoglottis adducta is most similar to S. muluensis by the presence of an elongated partially naked interstice separating the pistillate and staminate florets, and scattered ascending-clavate waxy white pistillatezone staminodes, but readily distinguished by the blunt bullet-shaped spadix appendix (in $S$. muluensis the appendix cylindrical) two thirds the length of the staminate zone (in S. muluensis the appendix twice as long as staminate zone), by the pistillate floret zone comprising about one half of the spadix length (in S. muluensis the pistillate floret zone comprising slightly less than one third of the spadix), and dorsally fused to the spathe for about one third its length (vs not at all fused in S. muluensis). A bullet-shaped appendix occurs in S. giamensis and S. roh, from both of which S. adducta is distinguished by the elongated naked (vs abbreviated staminode-covered) interstice, and by having only the basal third (vs as least half) of the pistillate floret zone adnate to the spathe.

\section{Description}

Moderately robust colonial mesophytic herb 30-70 $\mathrm{cm}$ tall. Stems hypogeal, hapaxanthic, individual crowns linked by stout stolons about $10 \mathrm{~cm}$ long with internodes
3-9.5 $\mathrm{cm}$ long, 7-9 $\mathrm{mm}$ in diam., terminal active portion of stem slightly epigeal, erect. Leaves about 7 per crown; petiole $24-40 \mathrm{~cm}$ long, $1.8 \mathrm{~cm}$ wide at base, tapering to $3.5 \mathrm{~mm}$ wide at tip, ventrally weakly broadly channelled for $1 / 5$ of length, smooth, dull medium green with faint slightly darker green striations; petiolar sheath 7-9 cm long $\times 5-10 \mathrm{~mm}$ wide, up to $3 / 10$ of petiole length, persistent, fully attached, equal at both sides, slightly inrolled, tapering; blade 14-23.5 × 5.3-10.4 cm, narrowly hastato-cordate to rather broadly ovato-cordate, margins slightly undulate in the largest leaves, adaxially semimatte rather dark green, posterior lobes bluntly triangular, 3-4 cm, sinus narrow, blade apex acute, ultimately tubular-mucronate for $1 \mathrm{~cm}$; midrib adaxially slightly impressed, rounded-raised abaxially, about $7 \mathrm{~mm}$ wide at the insertion on petiole; primary lateral veins about 15 per side, diverging at $40^{\circ}-60^{\circ}$ from midrib, adaxially impressed, rounded raised abaxially alternating with rather fewer interprimary veins, these sometimes arising from near the base of more robust primary veins, especially in the lower half of the blade; secondary veins $0-2$ arising from each primary vein with 3-4 secondary veins raised from primary veins near to petiole insertion; tertiary veins inconspicuous. Blooms up to 3 produced in sequence, erect and powerfully estericsmelling during anthesis; peduncle $14-20 \mathrm{~cm}$ long $\times 4-9$ $\mathrm{mm}$ wide, terete, medium green. Spathe $9.5 \mathrm{~cm}$ long; lower spathe narrowly oblong-ovoid, $4.5 \mathrm{~cm}$ long $\times 1.5$ $\mathrm{cm}$ wide, base dorso-ventrally oblique for $40 \%$ (ventral side) to $25 \%$ (dorsal side) the length of the entire spathe, semi-glossy medium green, usually smooth; spathe limb at pistillate anthesis limb much inflated, turbinate, apex briefly mucronate, surrounding the spadix and gaping ventrally, greenish white with darker longitudinal veins, caducous immediately after pistillate anthesis. Spadix 7 $\mathrm{cm}$ long, about three quarters length of the spathe; pistillate floret zone slender conic, $3 \mathrm{~cm}$ long $\times 7 \mathrm{~mm}$ wide, comprising $40 \%$ of spadix length, white, basal third adnate to the spathe; pistils densely arranged, sub-globose-cylindric, $1 \mathrm{~mm}$ diam.; style distinct, very short; stigma capitate, somewhat domed, slightly narrower than ovary, $0.8 \mathrm{~mm}$ diam.; interpistillar staminodes few and scattered, ascending-clavate, stipe slender, upwards curved, $3 \mathrm{~mm}$ long, about twice as tall as pistils, waxy white; sterile interstice cylindric, $7 \mathrm{~mm}$ long $\times 3.5 \mathrm{~mm}$ wide, narrower than fertile zones, partially naked, proximally and distally with flattened wedge-shaped staminodes these grading into disproportionately larger (but sterile) florets, female proximally, male distally; staminate flower zone weakly obconic, $2 \mathrm{~cm}$ long $\times 4 \mathrm{~mm}$ wide, slightly under $30 \%$ the length of spadix, white; staminate florets very densely packed with individual 

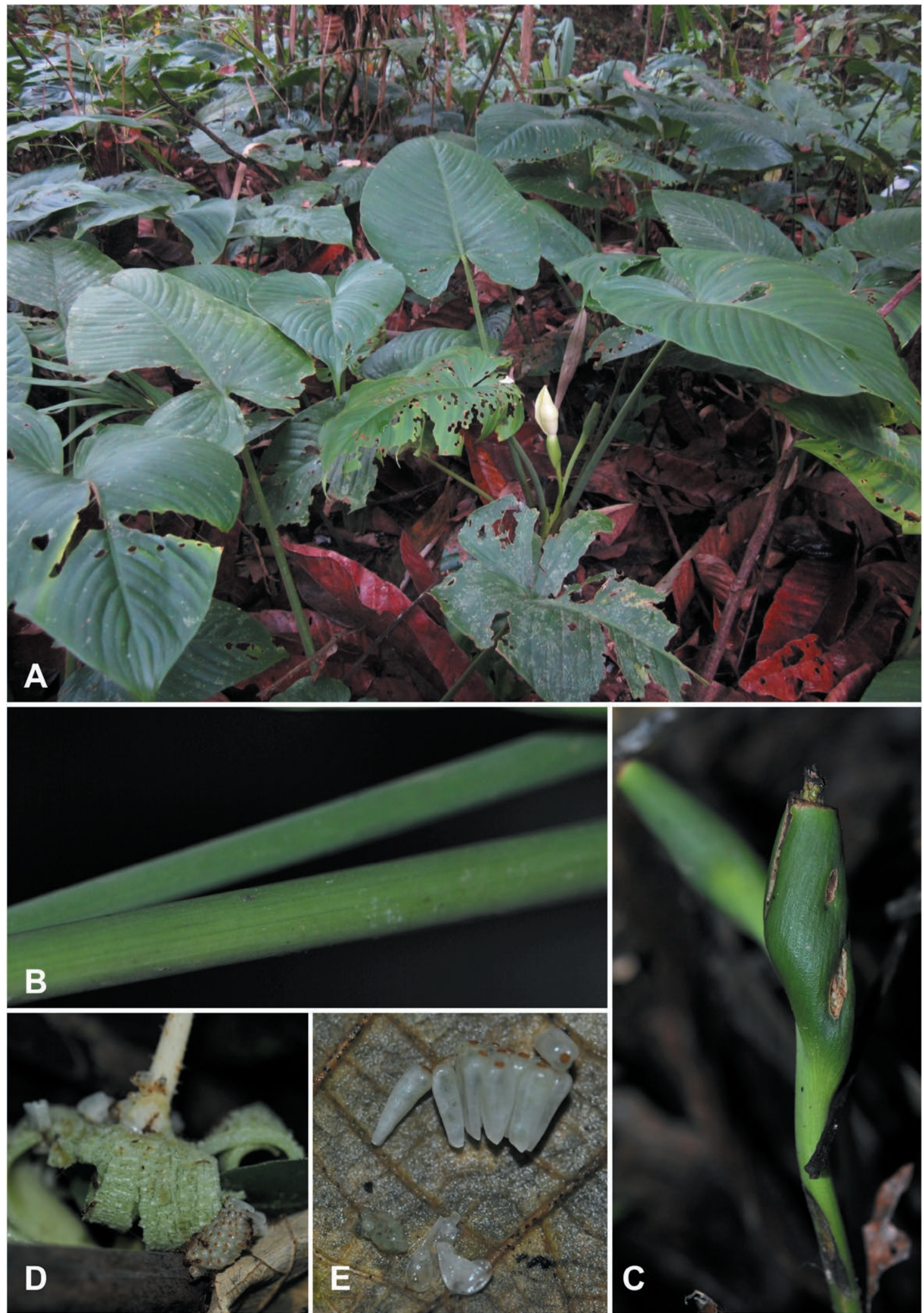

Figure 1. Schismatoglottis adducta S. Y. Wong \& P. C. Boyce. A. Plant in habitat. B. Detail of petiole. C. Developing infructescence. D. Ripe infructescence with the persistent spathe splitting and reflexing. E. Fallen ripe fruits. A-D from AR-1632. Images $\odot$ Hoe Yin Chen. 


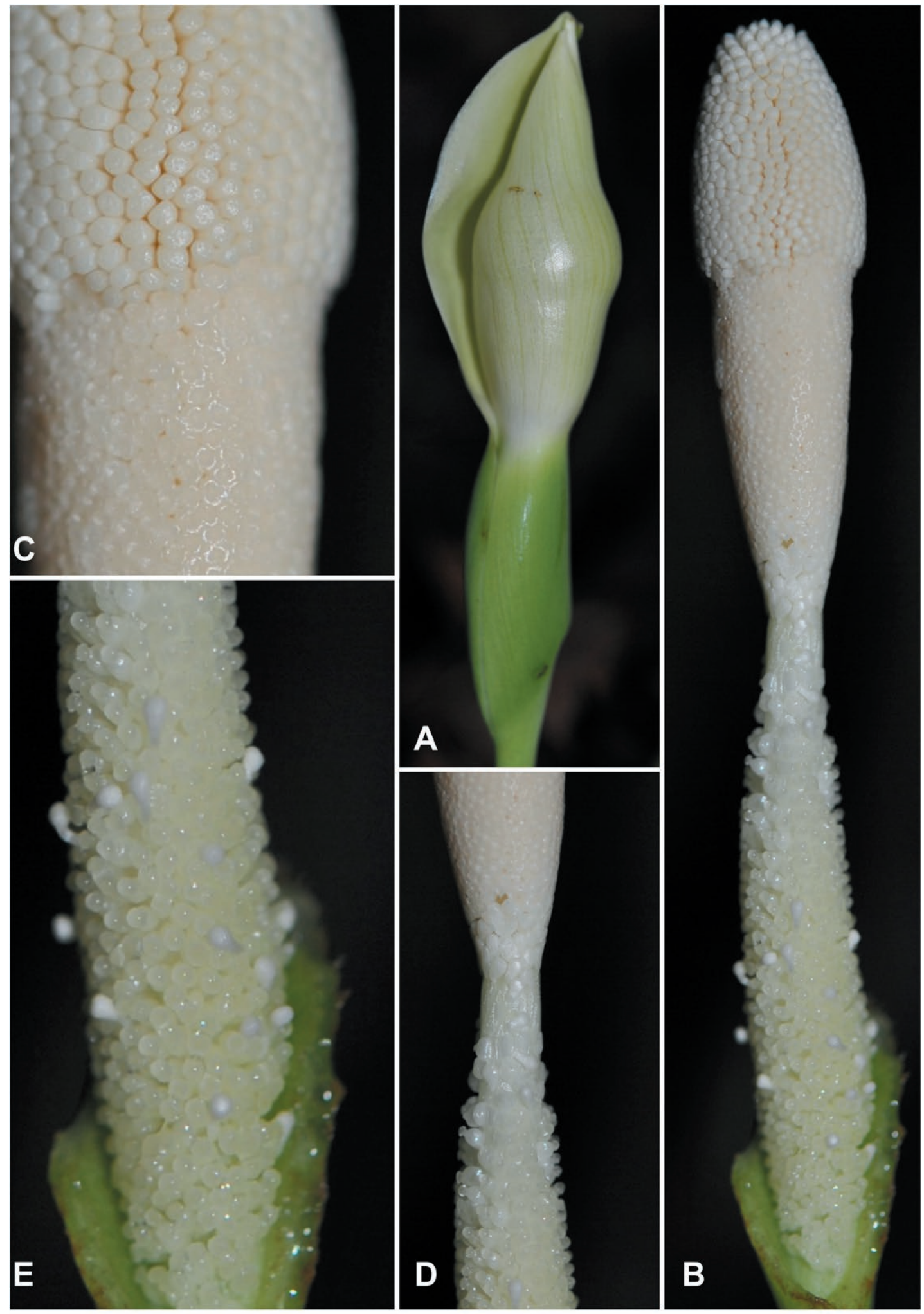

Figure 2. Schismatoglottis adducta S. Y. Wong \& P. C. Boyce. A. Bloom at pistillate anthesis. B. Spadix at pistillate anthesis, spathe artificially removed. C. Detail of spadix, uppermost portion of staminate floret zone, and most of appendix. D. Detail of spadix, uppermost portion of pistillate floret zone, sterile interstice, and lowermost portion of staminate floret zone. E. Detail of pistillate floret zone. A-E from AR-1632. Images (c) Hoe Yin Chen. 
florets hardly discernible, $0.6 \mathrm{~mm}$ wide, each comprising 2 truncate stamens, thecae very slightly sunken, surrounded by a narrow, raised rim and separated by a raised blunt connective; appendix bullet-shaped, 1.25 $\mathrm{cm}$ long $\times 7 \mathrm{~mm}$ wide, $15 \%$ length of spadix, base wider (about $1 \mathrm{~mm}$ ) than apex of staminate zone, white; staminodes columnar with rounded tops, $2.5 \mathrm{~mm}$ long $\times 1$ $\mathrm{mm}$ wide. Infructescence on a declinate peduncle, narrowly urceolate, dorsal side of the base strongly oblique, 4-6 cm long $\times 2-2.2 \mathrm{~cm}$ wide, deep green; lower spathe persistent, maturing to deep green on a paler peduncle, splitting and reflexing at fruit maturity; fruits obconic, $4 \mathrm{~mm}$ long $\times 1-2.5 \mathrm{~mm}$ wide, ripening semi-translucent white; seeds ovoid ellipsoid, $0.4 \mathrm{~mm}$ diam., longitudinally ridged.

\section{Etymology}

From Latin adductus - stretched, used in reference to the elongated distal portion of the sterile interstice separating the zones of pistillate and staminate florets.

\section{Distribution}

Widespread and locally abundant along the banks of the Batang Lupar and Sungai Raya near Sri Aman.

\section{Ecology}

Occurring in deep alluvial sandy clays over Eocene or Cretaceous sediments at low altitude under moist alluvial riverine forest.

\section{Notes}

Pollination biology data for Schismatoglottis adducta (and the other species covered here) are presented in Hoe et al. (2018). In summary pollination involves thermogenesis and floral odour production and consists of a biphasic pattern of thermogenesis in the appendix and the staminate zone with the first temperature peak occurring during pistillate anthesis and the second during staminate anthesis. During inter-anthesis, thermogenesis ceases, with the ambient temperature remaining higher than that of the spadix. Methyl ester- 3-methyl3-butenoic acid is the single major compound in the floral scent profile, and the appendix the main olfactory structure. Colocasiomyia flies are the primary pollinators with Cycreon (Hydrophilidae) beetles secondary pollinators for all except $S$. muluensis for which Atheta (Staphylinidae) beetles are the primary pollinators.

\section{Additional specimen examined (paratypes}

MALAYSIAN BORNEO: Sarawak: Sri Aman Division. Lubok Antu, Engkililii, Tempat Rekreasi Batu
Ngabau, $1^{\circ} 11^{\prime} 8.61^{\prime \prime} \mathrm{N} 111^{\circ} 40^{\prime} 11.83^{\prime \prime} \mathrm{E}, 40 \mathrm{~m}$ asl., 28 Aug 2012, Hoe Yin Chen AR-4023 (SAR!).

Schismatoglottis baangongensis S.Y.Wong, Y.C.Hoe \& P.C.Boyce, Aroideana 39(2): 80. 2016.

Type:- Malaysian Borneo. Sarawak, Kuching Division, Padawan, Siburan, Kampung Sikog, trail to Baan Gong waterfall, $01^{\circ} 020^{\prime} 16.1^{\prime \prime} \mathrm{N}, 110^{\circ} 20^{\prime} 09.6^{\prime} \mathrm{E}, 26 \mathrm{Jul} 2009$, P.C.Boyce \& S.Y.Wong AR-2588 (holotype SAR!; isotype SAR - spirit!). (Figures 3, 4 and 14B).

\section{Description}

Moderately robust clumping to colonial mesophytic herb, 30-90 cm tall. Stems hypogeal, hapaxanthic, 0.5-1.5 cm diam., producing several stolons from each crown. Leaves 3-5 per crown; petiole, $42-48 \mathrm{~cm}$ long, weakly channelled $1 / 5$ of length, smooth medium green, distally with prominent broken longitudinal darker green raised striations; petiolar sheath $11-14 \mathrm{~cm}$ long $\times$ 5-10 mm wide, up to $3 / 10$ of petiole length, persistent, longitudinal striated, membranous, fully attached or (in very robust specimens) with a very short ligule, equal at both sides, slightly in-rolled or sometimes straight, tapering; blades ovato-sagittate to ovato-cordate, sometimes oblong-lanceolate, base cordate base, $20-39 \mathrm{~cm}$ long $\times 13-23 \mathrm{~cm}$ wide, softly coriaceous, adaxially glossy green, abaxially paler, posterior lobes subtriangular, 7-11 cm, sinus $8-11 \mathrm{~cm}$ wide, apex acuminate to acute for $2 \mathrm{~cm}$, ultimately mucronate for $1 \mathrm{~cm}$; midrib adaxially flush with blade, raised abaxially, $5 \mathrm{~mm}$ wide at the insertion; primary lateral veins 14 per side, diverging at $30^{\circ}-80^{\circ}$ from midrib, adaxially raised towards the midrib, marginally impressed, entirely raised abaxially; interprimary veins adaxially raised, alternating irregularly with primaries; secondary veins $0-2$ arising from each primary vein with 3-4 secondary veins arising from primary veins near to petiole insertion; tertiary veins inconspicuous; broken vein-like pellucid canals slightly visible abaxially. Blooms up to 4 together per shoot, erect, strongly esteric-smelling during pistillate anthesis, odour absent during staminate anthesis; peduncle $10-15 \mathrm{~cm}$ long $\times 4-9 \mathrm{~mm}$ wide, terete, green, erect at anthesis. Spathe 11-12.5 cm long; lower spathe narrowly ovoid, $4 \mathrm{~cm}$ long $\times 2.3 \mathrm{~cm}$ wide, green, longitudinally ridged, demarcated from spathe limb by a constriction coinciding with sterile interstice; spathe limb turbinate, ovate when flattened, $6.5 \mathrm{~cm}$ long $\times 3.3$ $\mathrm{cm}$ wide, mucronate for $2 \mathrm{~mm}$, pale yellowish green at pistillate anthesis, ageing to dull pale yellow during anthesis, caducous in a single piece at onset of staminate 

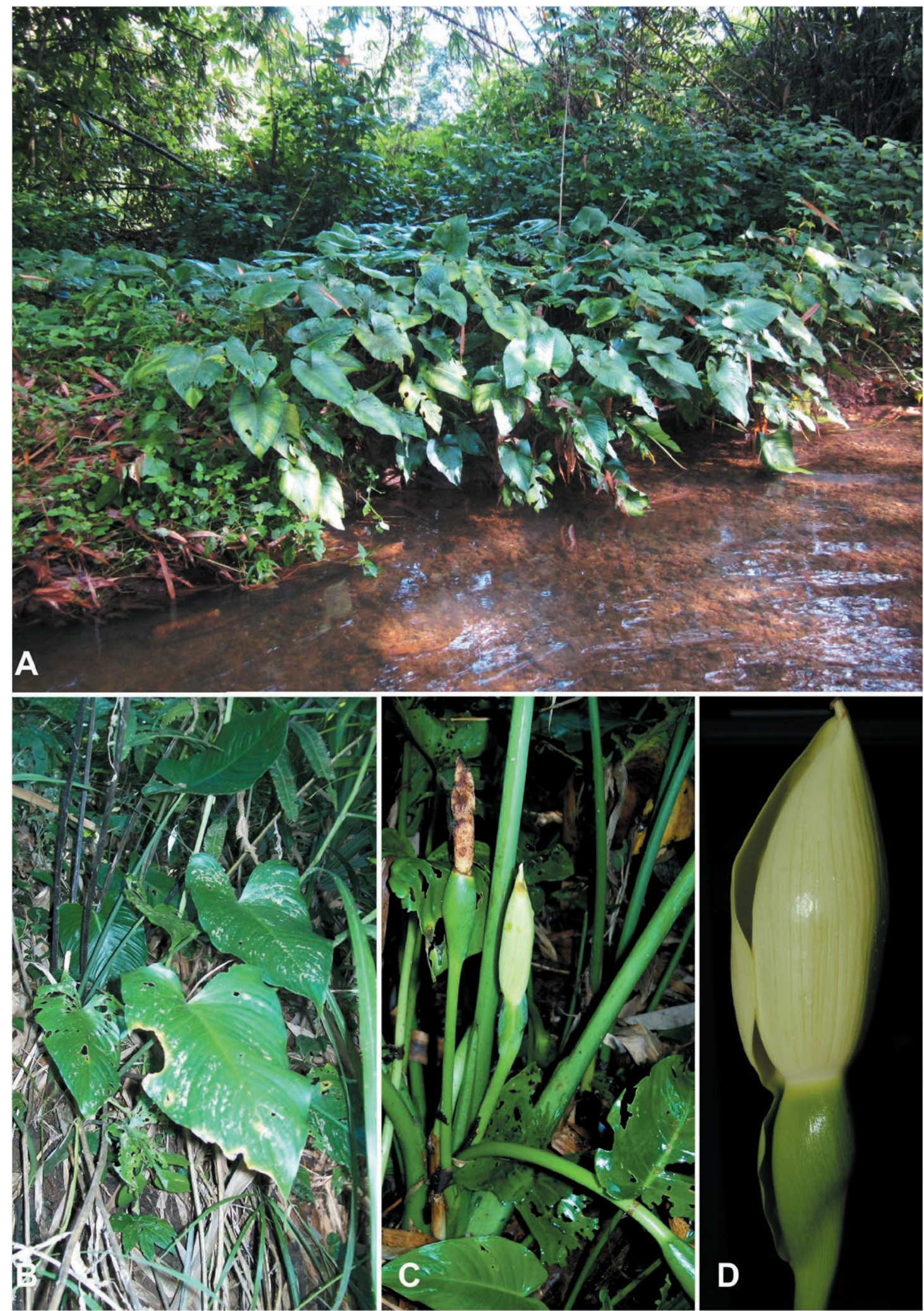

Figure 3. Schismatoglottis baangongensis S. Y. Wong, Y. C. Hoe \& P. C. Boyce. A \& B. Plants in habitat. C. Detail of synflorescence, with one bloom post-anthesis (left), and one at pistillate anthesis (right). D. Bloom at pistillate anthesis. A-D from AR-2588. Images $\odot$ Hoe Yin Chen. 


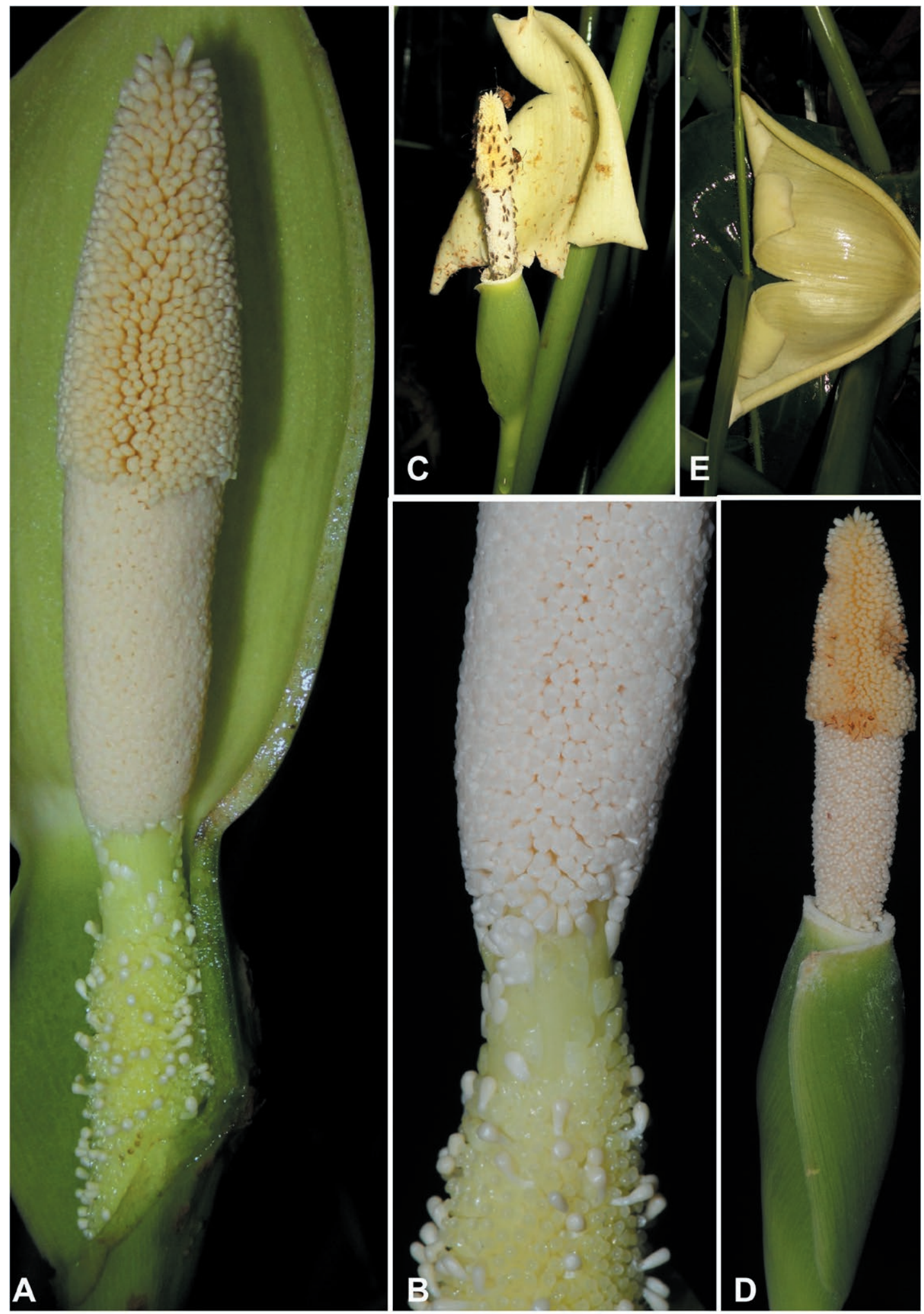

Figure 4. Schismatoglottis baangongensis S. Y. Wong, Y. C. Hoe \& P. C. Boyce. A. Bloom at pistillate anthesis, nearside spathe artificially removed. B. Detail of spadix, uppermost portion of pistillate floret zone, sterile interstice, and lowermost portion of staminate floret zone. C. Bloom at onset of staminate anthesis with spathe limb beginning to shed. D. Bloom post anthesis with spathe limb shed. E. Caducous spathe limb. A-E from AR-2588. Images ( $)$ Hoe Yin Chen. 
anthesis. Spadix 9-10.5 cm long, shorter than spathe, sessile; pistillate flower zone slender obconic, $4-5 \mathrm{~cm}$ long $\times 1 \mathrm{~cm}$ wide, $2 / 5$ of spadix length, bright green; pistils densely arranged, sub-cylindric to sub-globose, $0.8-1.2 \mathrm{~mm}$ diam.; style barely differentiated; stigma globose, truncate, smaller than ovary, $0.3 \mathrm{~mm}$ diam.; interpistillar staminodes numerous, strongly clavate, stipe slender, $0.5-0.8 \mathrm{~mm}$ in diam., twice height of pistils, waxy white; sterile interstice cylindric, $0.5-1 \mathrm{~cm}$ long $\times 5-6.5 \mathrm{~mm}$ wide, narrower than pistillate and staminate zone, partially naked, proximally and distally with flattened trapezoid staminodes; staminate flower zone weakly conic, proximally narrower, $2.2-2.7 \mathrm{~cm}$ long $\times$ 9-12 mm wide, 3/10 length of spadix, yellowish white; staminate florets densely arranged, butterfly-shaped from above, $1 \mathrm{~mm}$ long $\times 0.5 \mathrm{~mm}$ wide, each comprising 2 truncate stamens, thecae sunken, separated by a narrow, raised connective; appendix conical, $2.2-2.5 \mathrm{~cm}$ long $\times 1 \mathrm{~cm}$ wide, $3 / 10$ length of spadix, base wider $(1$ $\mathrm{mm})$ than apex of staminate zone, creamy yellow; staminodes columnar, $2.5 \mathrm{~mm}$ long $\times 1.2 \mathrm{~mm}$ wide, somewhat laxly arranged with diverging tips, giving appendix a coarsely papillate appearance, creamy yellow. Infructescence urceolate, $4-6 \mathrm{~cm}$ long $\times 2-2.2 \mathrm{~cm}$ wide, on a declinate peduncle; lower spathe persistent, splitting and reflexing at fruit maturity; fruits $2-4 \mathrm{~mm}$ long $\times 1-2.5$ $\mathrm{mm}$ wide, green to yellow; seeds ovoid ellipsoid, $0.4 \mathrm{~mm}$ diam., 13-22 per fruit, encased by greenish yellow gel.

\section{Etymology}

Derived from the name of the type locality plus the Latin suffix, -ensis, to indicate origin.

\section{Distribution}

Schismatoglottis baangongensis is known from the type locality and its vicinity.

\section{Ecology}

Terrestrial in perhumid lowland forest associated with (but never occurring epilithically on) Jurassic Karst limestone, often forming dense stands along trails bordering to small streams, $70-75 \mathrm{~m}$ asl.

\section{Schismatoglottis giamensis S.Y.Wong, Y.C.Hoe \& P.C.Boyce, sp. nov.}

Type: Malaysian Borneo. Sarawak: Kuching Division, Siburan, Kampung Giam, Sugun Jawan, 1'19'20.7”N $110^{\circ} 16^{\prime} 21.4^{\prime \prime}$ E, $70 \mathrm{~m}$ asl., 20 Jun 2009, Wong Sin Yeng \& P.C.Boyce AR-2549 (holotype SAR!). (Figures 5, 6 and 14C).

\section{Diagnosis}

Schismatoglottis giamensis most closely resembles $S$. baangongensis and S.roh by the bullet shaped appendix, but is distinguished among the three by having almost the entire pistillate floret zone dorsally adnate to the spathe (vs at most half pistillate zone dorsally adnate). Schismatoglottis giamensis is further distinguished from $S$. baangongensis and from $S$. roh by the larger stamens with thecae having a thickened rim, and additionally from $S$. baangongensis by the pistillate zone with the lower part narrowing and then the base expanding at the junction of pistillate zone the interstice (vs pistillate zone uniformly narrowing all the way to the base).

\section{Description}

Moderately robust colonial mesophytic herb, up to $1 \mathrm{~m}$ tall. Stem hypogeal, hapaxanthic, individual crowns arising from and producing further slender stolons, terminal active portion of stem somewhat epigeal, erect, stolons $10 \mathrm{~cm}$ long, internodes $3-9.5 \mathrm{~cm}$ long, 7-9 $\mathrm{mm}$ in diam. Leaves about 7 per crown; petiole $24-40$ $\mathrm{cm}$ long, $1.8 \mathrm{~cm}$ wide at base, tapering to $3.5 \mathrm{~mm}$ wide at tip, weakly broadly channelled ventrally for $1 / 5$ of length, smooth, medium green with faint darker green striations; petiolar sheath 7-9 $\mathrm{cm}$ long $\times 5-10 \mathrm{~mm}$ wide, up to $3 / 10$ of petiole length, persistent, fully attached, equal at both sides, slightly in-rolled, tapering; blade $14-23.5 \times 5.3-10.4 \mathrm{~cm}$, narrowly hastato-cordate to rather broadly ovato-cordate, margins very slightly undulate in the largest leaves, adaxially semi-matte medium green; posterior lobes triangular, $3-4 \mathrm{~cm}$, sinus narrow, blade apex acute, ultimately tubular-mucronate for 1 $\mathrm{cm}$; midrib adaxially slightly impressed, rounded-raised abaxially, $7 \mathrm{~mm}$ wide at the insertion on petiole; primary lateral veins 12 per side, diverging at $40^{\circ}-60^{\circ}$ from midrib, adaxially impressed, rounded and? raised abaxially, alternating with about the same number of interprimary veins, these sometimes arising from near the base of more robust primary veins; secondary veins $0-2$ arising from each primary vein with 3-4 secondary veins arising from primary veins near to petiole insertion; tertiary veins inconspicuous. Blooms up to 7 produced in sequence, erect, very powerfully esteric-smelling during anthesis; peduncle $10-25 \mathrm{~cm}$ long $\times 4-9 \mathrm{~mm}$ wide, terete, dark green with deeper green broken longitudinal lines, erect at anthesis. Spathe about $10 \mathrm{~cm}$ long; lower spathe oblong-ovoid, $4.5 \mathrm{~cm}$ long $\times 1.5 \mathrm{~cm}$ wide, at base strongly dorso-ventrally oblique, $40 \%$ (ventral side) to $25 \%$ (dorsal side) the length of the whole spathe, semi-glossy medium green, usually smooth; spathe limb differentiated from lower spathe by an abrupt constriction corresponding to the base of the male zone of the 

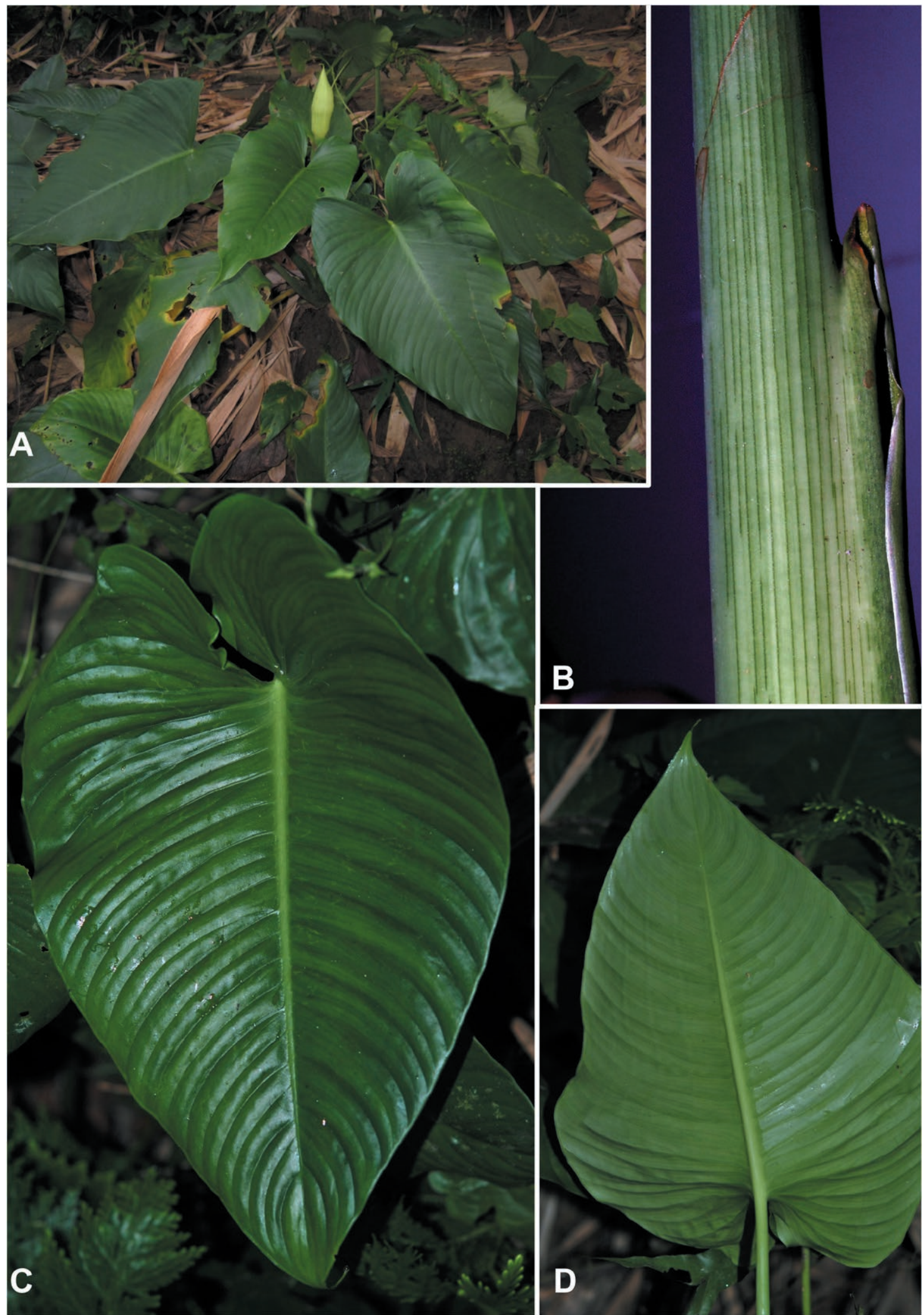

Figure 5. Schismatoglottis giamensis S. Y. Wong \& P. C. Boyce. A. Plant in habitat. B. Detail of petiole showing the characteristic deep green striae. C. Leaf blade, adaxial surface. D. Leaf blade, abaxial surface. A-D from AR-2549. Images @ P.C. Boyce. 


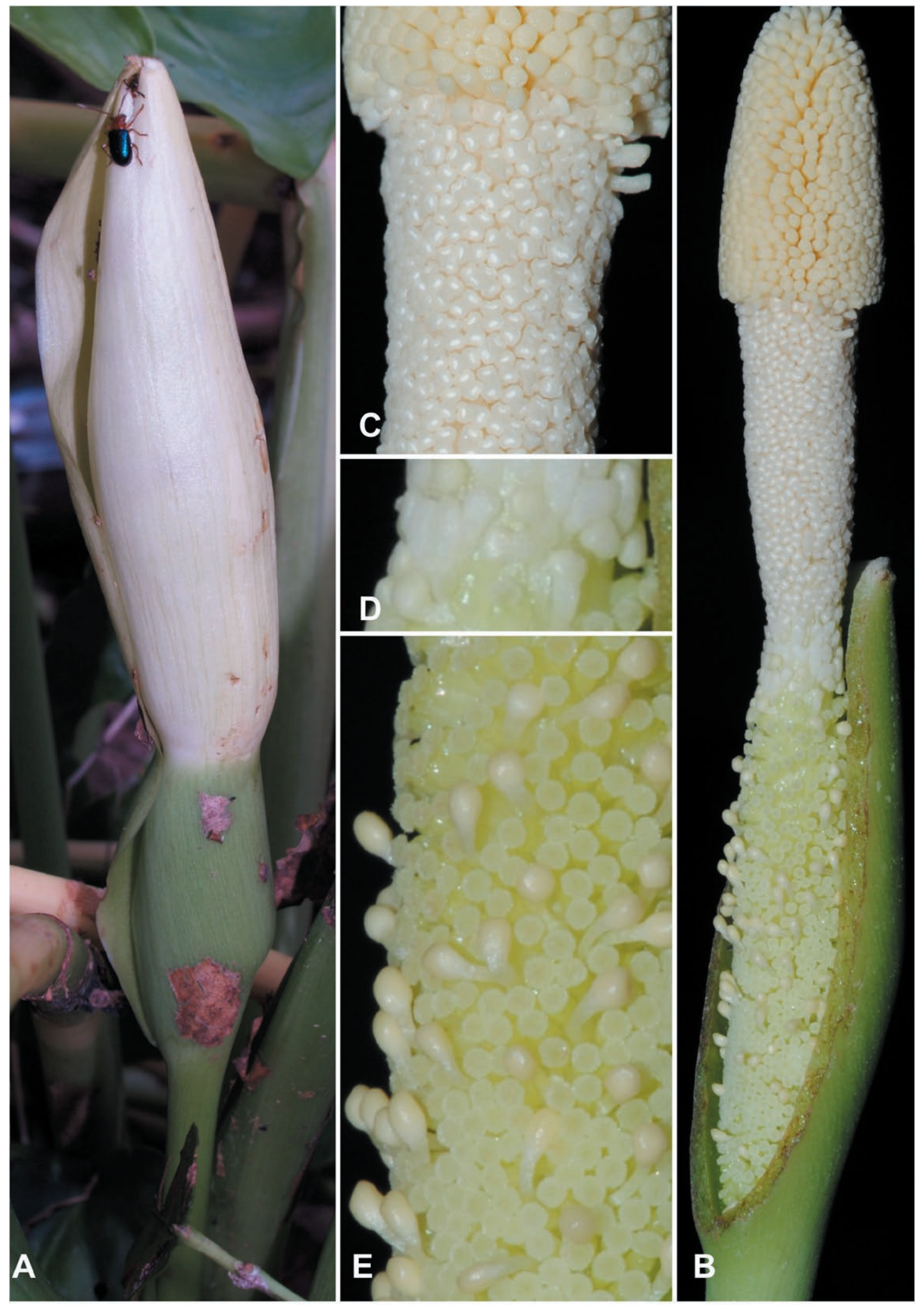

Figure 6. Schismatoglottis giamensis S. Y. Wong \& P. C. Boyce. A. Bloom at pistillate anthesis. B. Spadix at pistillate anthesis, spathe artificially removed. C. Detail of spadix, uppermost portion of staminate floret zone and lowermost part of appendix. D. Detail of interstice. E. Detail of pistillate floret zone. A-E from AR-2549. Images (C P.C. Boyce. 
spadix, at pistillate anthesis much inflated, turbinate, the apex briefly mucronate, completely surrounding the spadix and gaping ventrally, lime green, caducous immediately after pistillate anthesis. Spadix $7 \mathrm{~cm}$ long, about three quarters length of the spathe; pistillate floret zone stoutly sub-conic, $3 \mathrm{~cm}$ long $\times 7 \mathrm{~mm}$ wide, comprising $50 \%$ of spadix length, pale green; pistils densely arranged, sub-globose-cylindric, $1 \mathrm{~mm}$ diam.; style distinct, very short; stigma capitate, somewhat domed, about two thirds the width of the ovary, 0.8 $\mathrm{mm}$ diam.; interpistillar staminodes numerous, scattered, ascending-clavate, stipe slender, upwards curved, $3 \mathrm{~mm}$ long, about twice as tall as pistils, creamy white; sterile interstice indistinct, slightly narrower than fertile zones, clothed with somewhat deformed pistils (proximally) and staminate florets (distally); staminate floret zone weakly obconic, $3 \mathrm{~cm}$ long $\times 4 \mathrm{~mm}$ wide, about $30 \%$ the length of spadix, white; staminate florets very densely packed with individual florets hardly discernible and irregularly orientated, $0.6 \mathrm{~mm}$ wide, each comprising 2 truncate stamens, thecae very slightly sunken, surrounded by a broad rim; appendix bullet-shaped, $1.25 \mathrm{~cm}$ long $\times 7 \mathrm{~mm}$ wide, $25 \%$ length of spadix, base wider than the apex of the staminate zone, creamy; staminodes columnar with rounded tops, $2.5 \mathrm{~mm}$ long $\times 1$ $\mathrm{mm}$ wide. Infructescence on a declinate peduncle, narrowly urceolate, dorsal side of the base strongly oblique, $4-6 \mathrm{~cm}$ long $\times 2-2.2 \mathrm{~cm}$ wide, deep green; lower spathe persistent, splitting and reflexing at fruit maturity; fruits $4 \mathrm{~mm}$ long $\times 1-2.5 \mathrm{~mm}$ wide, ripening semi-translucent white; seeds ovoid ellipsoid, $12-40$ per fruit, $0.4 \mathrm{~mm}$ diam., longitudinally ridged.

\section{Etymology}

Derived from the name of the type locality plus the Latin suffix, -ensis, to indicate origin.

\section{Distribution}

Known only from the type locality.

\section{Ecology}

In open perhumid lowland forest in alluvial sandy clay overlying Triassic volcanics.

Schismatoglottis muluensis M.Hotta, Mem. Coll. Sci. Kyoto Imp. Univ., Ser. B, Biol. 32(3): 235. 1966.

Type: Malaysian Borneo. Sarawak, [Miri], Marudi ("Mardi"), western ridge of Gunung Mulu, 17 Mar 1964, M. Hotta 14623 (holotype KYO!). (Figures 7, 8 and 14D).

\section{Description}

Medium to moderately robust epilithic clumping herb 30-80 cm tall. Stems hypogeal, hapaxanthic, $2 \mathrm{~cm}$ diam. Leaves 3-5 per crown; petiole D-shaped, smooth, 34-47 cm long, green, weakly channelled for about $1 / 3$ its length, longitudinal striations conspicuous but not noticeably darker; petiolar sheath $8-14 \mathrm{~cm}$ long $\times 5-10$ mm wide, sheathing for $1 / 4-1 / 3$ of petiole length, persistent, membranous, fully attached with a very short ligule in very robust plants, wings slightly in-rolled or sometimes straight, tapering, scattered with greenish dots; leaf blade ovato-sagittate to ovato-cordate, $25-27 \mathrm{~cm}$ long $\times 13-25.5 \mathrm{~cm}$ wide, leathery, adaxially semi-glossy dark green, abaxially paler, posterior lobes subtriangular to rounded, $4.5-8 \mathrm{~cm}$, sinus $3.5-6 \mathrm{~cm}$ wide, apex acute to acuminate for 1-2 $\mathrm{cm}$, ultimately with a $4 \mathrm{~mm}$ tubular mucro; midrib adaxially flush with blade, raised abaxially, 3.5-6 $\mathrm{mm}$ at insertion; primary lateral veins 16 per side, diverging at $30^{\circ}-80^{\circ}$ from the midrib, raised adaxially towards the midrib, marginally impressed, entirely raised abaxially; interprimary veins raised adaxially, alternating irregularly with primaries; secondary veins 3-4 arising from each primary vein; tertiary veins inconspicuous; vein-like pellucid canals clearly visible abaxially. Blooms 1-3 together, erect, smelling strongly esteric during pistillate anthesis, floral odour absent during staminate anthesis; peduncle 10-19 $\mathrm{cm}$ long $\times 6$ $\mathrm{mm}$ wide, long, terete, green, erect at anthesis. Spathe 10 $\mathrm{cm}$ long; lower spathe ovoid-ellipsoid, $4 \mathrm{~cm}$ long $\times 1.7$ $\mathrm{cm}$ wide, dull green, demarcated from spathe limb by a conspicuous constriction coinciding with lower part of staminate zone; spathe limb weakly turbinate at anthesis (triangular-ovate pressed flat), $6.5 \mathrm{~cm}$ long $\times 2.5 \mathrm{~cm}$ wide, mucronate for $5 \mathrm{~mm}$, pale greenish yellow to pure white at pistillate anthesis, caducous in a single piece at onset of staminate anthesis. Spadix $9 \mathrm{~cm}$ long, shorter than spathe, sessile, free; pistillate flower zone cylindric, $3 \mathrm{~cm}$ long $\times 7 \mathrm{~mm}$ wide, $2 / 5$ length of spadix, creamy yellow; pistils densely arranged, sub-globose, $1 \mathrm{~mm}$ long $\times 0.4 \mathrm{~mm}$ wide; style barely differentiated; stigma sub-globose, wider than ovary, $0.5 \mathrm{~mm}$ diam., wet with stigmatic secretion at the onset of pistillate anthesis; interpistillar staminodes very few and scattered, weakly clavate, stipe slender, $0.5 \mathrm{~mm}$ in diam., up to twice height of pistils, waxy white; interstice cylindric, $6 \mathrm{~mm}$ long $\times 5-7 \mathrm{~mm}$ wide, partially naked, narrower than fertile zones, white, distally with 2-5 whorls of flattened spheroid staminodes, these intergrading into lower part of staminate zone, proximally pistillodes compressed, intergrading into the upper pistillate zone; staminate flower zone weakly obconic, narrower proximally, 1.8 $\mathrm{cm}$ long $\times 5.5 \mathrm{~mm}$ wide, $2 / 7$ length of spadix, white; 

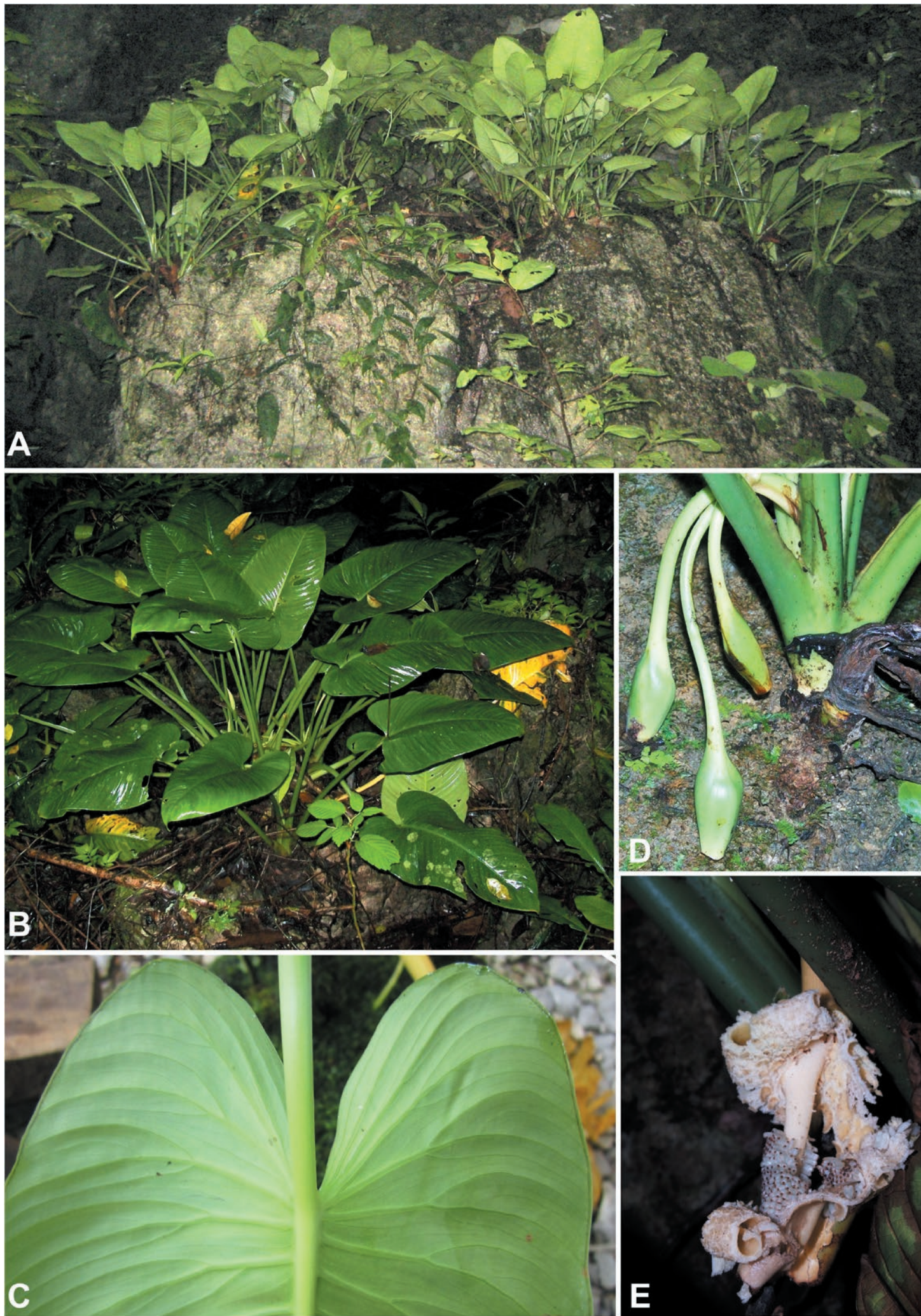

Figure 7. Schismatoglottis muluensis M. Hotta. A \& B Plants in habitat occurring lithophytically on limestone. C. Abaxial side of leaf blade showing secondary veins arising from primary laterals. D. Developing infructescences. E. Ripe infructescence splitting to reveal fruits; naked portion of axis is where fruits have already been dispersed. A-E from AR-1949. Images () P.C. Boyce. 

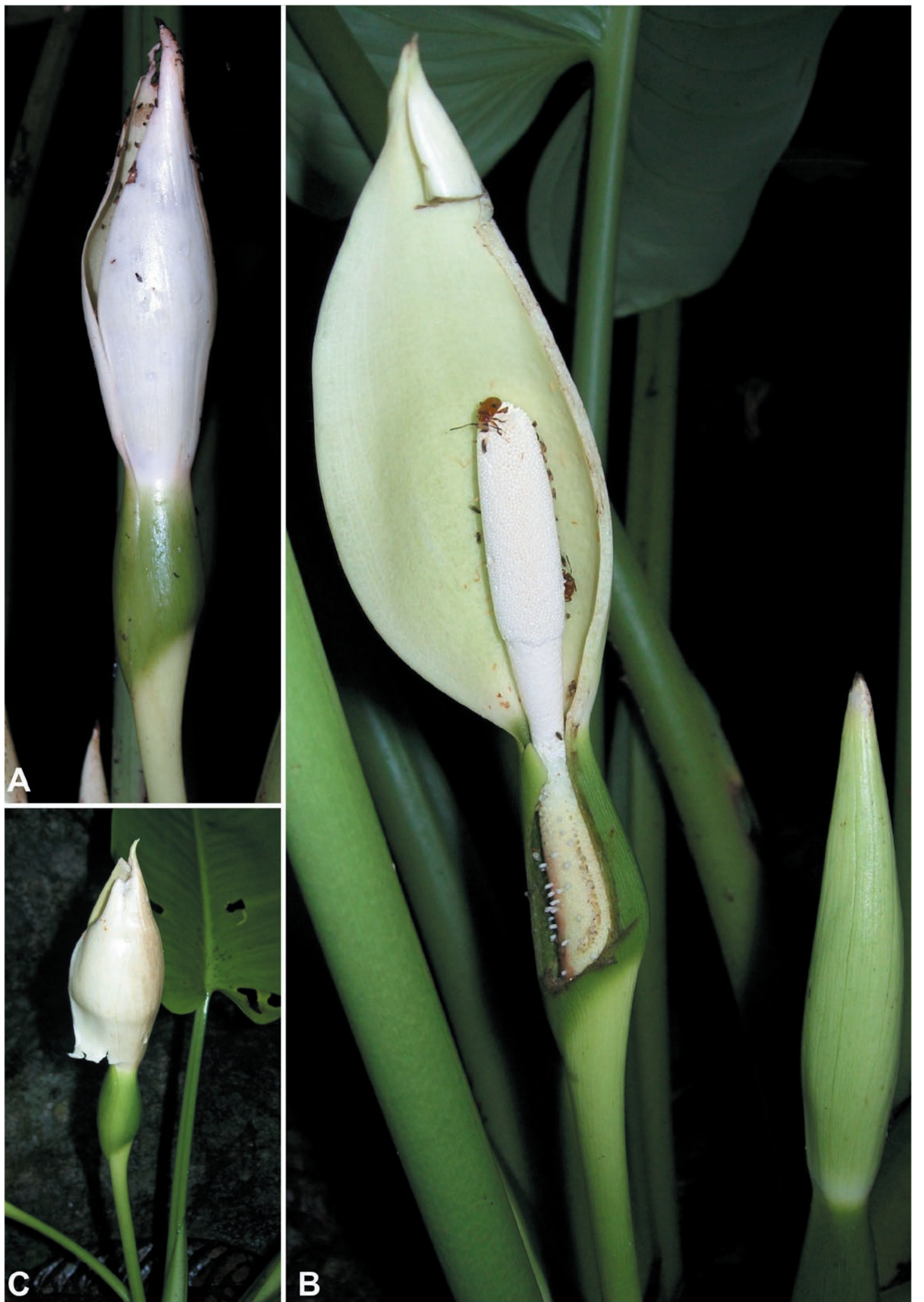

Figure 8. Schismatoglottis muluensis M. Hotta. A. Bloom at mid-pistillate anthesis. B. Spadix at late pistillate anthesis, part of spathe artificially removed. Note that many of the interpistillar staminodes have been eaten. C. Bloom at onset of staminate anthesis with spathe limb beginning to shed. A-C from AR-1949. Images ( P.C. Boyce. 
staminate florets densely arranged, $1 \mathrm{~mm}$ long $\times 0.5 \mathrm{~mm}$ wide, each comprising 2 truncate stamens; thecae separated by a narrow raised connective; appendix stoutly cylindric, $2 \mathrm{~cm}$ long $\times 5.5 \mathrm{~cm}$ wide, $2 / 7$ length of spadix, base slightly $(0.2 \mathrm{~mm})$ wider than top of staminate zone, white; appendix staminodes densely arranged, sub-globose to sub-columnar, $1 \mathrm{~mm}$ long $\times 0.5 \mathrm{~mm}$ wide, white. Infructescences $1-4,5 \mathrm{~cm}$ long $\times 2 \mathrm{~cm}$ wide, pendulous; lower spathe entirely persistent, splitting-reflexing when ripe; fruits $2 \mathrm{~mm}$ long $\times 1.5 \mathrm{~mm}$ wide, green to very pale yellow-green; seeds ovoid ellipsoid, $0.4 \mathrm{~mm}$ diam., longitudinally ridged, 7-40 per fruit, encased in transparent viscous gel.

\section{Etymology}

Derived from the name of the type locality plus the Latin suffix, -ensis, to indicate origin.

\section{Distribution}

Endemic to Mulu.

\section{Ecology}

Schismatoglottis muluensis is restricted to shaded damp Karst limestone formations at Mulu N.P., where it is notably abundant along the trail to Deer Cave occurring epilithically under perhumid lowland tropical forest between 40 and $75 \mathrm{~m}$ asl.

Schismatoglottis niahensis A.Hay, Telopea 9: 137. 2000

Type: Cult. RBG Sydney Acc. No. 940512 ex Malaysia, Sarawak, Niah National Park, Niah Caves area (orig. coll. Hay et al. 9361), Nov 1997, C.Herscovitch s.n. (holotype SAR!; isotypes K!, KEP!, L!, NSW). (Figures 9, 10 and 14E).

\section{Description}

Robust herb $70 \mathrm{~cm}$ tall. Stem erect and largely epigeal, suckering, comprised of greatly elongated hapaxanthic modules, to $30 \mathrm{~cm}$ tall $\times 5 \mathrm{~cm}$ diam.; internodes $2 \mathrm{~cm}$ long. Leaves few together; petiole $40 \mathrm{~cm}$ long, sheathing in the lower $1 / 3-2 / 3$; wings of sheath tapering, fully attached; blade sagittate, mid-green adaxially, paler below, $28-35 \mathrm{~cm}$ long $\times 13-22 \mathrm{~cm}$ wide, widest at or near base, the base cordate with rounded posterior lobes 7-9 cm long; midrib flush with the lamina (dry), stout and broad, with 13 rather stout, adaxially pale green primary lateral veins on each side, irregularly alternating with lesser interprimaries, sometimes branched especially in the lower part of the anterior lobe, diverging at $70^{\circ}$ and almost straight for most of the way to the margin before deflecting distally; secondary venation rather obscure adaxially and abaxially, arising from the midrib and the primary veins; tertiary venation obscure. Blooms to 4 together, subtended by short cataphylls except the first subtended by a cataphyll reaching to half way along the spathe and bearing a reduced petiole and blade; peduncle $13-15 \mathrm{~cm}$ long. Spathe $11-15 \mathrm{~cm}$ long; lower spathe $4-5.5 \mathrm{~cm}$ long, narrowly ovoid, differentiated from the limb by a sharp constriction; limb ovate, $7-10 \mathrm{~cm}$ long, slightly inflated over the appendix, finally acuminate for $2 \mathrm{~cm}$, caducous. Spadix $9 \mathrm{~cm}$ long, narrowly hourglass-shaped; female zone $3.8 \mathrm{~cm}$ long, adnate to the spathe in the lower $1.2 \mathrm{~cm}, 8 \mathrm{~mm}$ diam. in the middle, distally conoid and apically $3 \mathrm{~mm}$ diam.; pistils crowded, narrowly cylindric (especially near the base of the female zone, distally somewhat lower and thicker), $0.5 \mathrm{~mm}$ diam.; stigma sessile, button-like, about the same diameter as the ovary; interpistillar staminodes scattered among the pistils, more crowded in the distal part of the female zone, long-stalked, apically abruptly clavate and flat-topped, 1.5 times the height of the ovary; sterile interstice $2-3 \mathrm{~mm}$ long, slightly obconic, 3-4 whorls of sterile stamens drying very dark brown, lying level with the mouth of the lower spathe; male zone obconic, $2.8 \mathrm{~cm}$ long, distally $1 \mathrm{~cm}$ diam.; stamens densely crowded, $0.5 \mathrm{~mm}$ across, dumbbell-shaped with large round pores and the connective slender and raised into a short broadly triangular point somewhat off-centre; appendix more or less bullet-shaped, at the base slightly but abruptly wider than the top of the male zone, $1.2 \mathrm{~cm}$ diam., then somewhat tapering and finally obtuse; staminodes of appendix columnar, flat-topped and irregularly polygonal with rounded angles, $0.5 \mathrm{~mm}$ diam. Infructescence not observed

\section{Etymology}

Derived from the name of the type locality plus the Latin suffix, -ensis, to indicate origin.

\section{Distribution}

Known only from Niah National Park.

\section{Ecology}

At the base of limestone bluffs surrounded by swamp forest at low altitudes.

Notes

Hay (Hay \& Yuzammi 2000) described the stems of $S$. niahensis as pleionanthic, whereas in fact they are hapaxanthic but unique in the clade for having much 

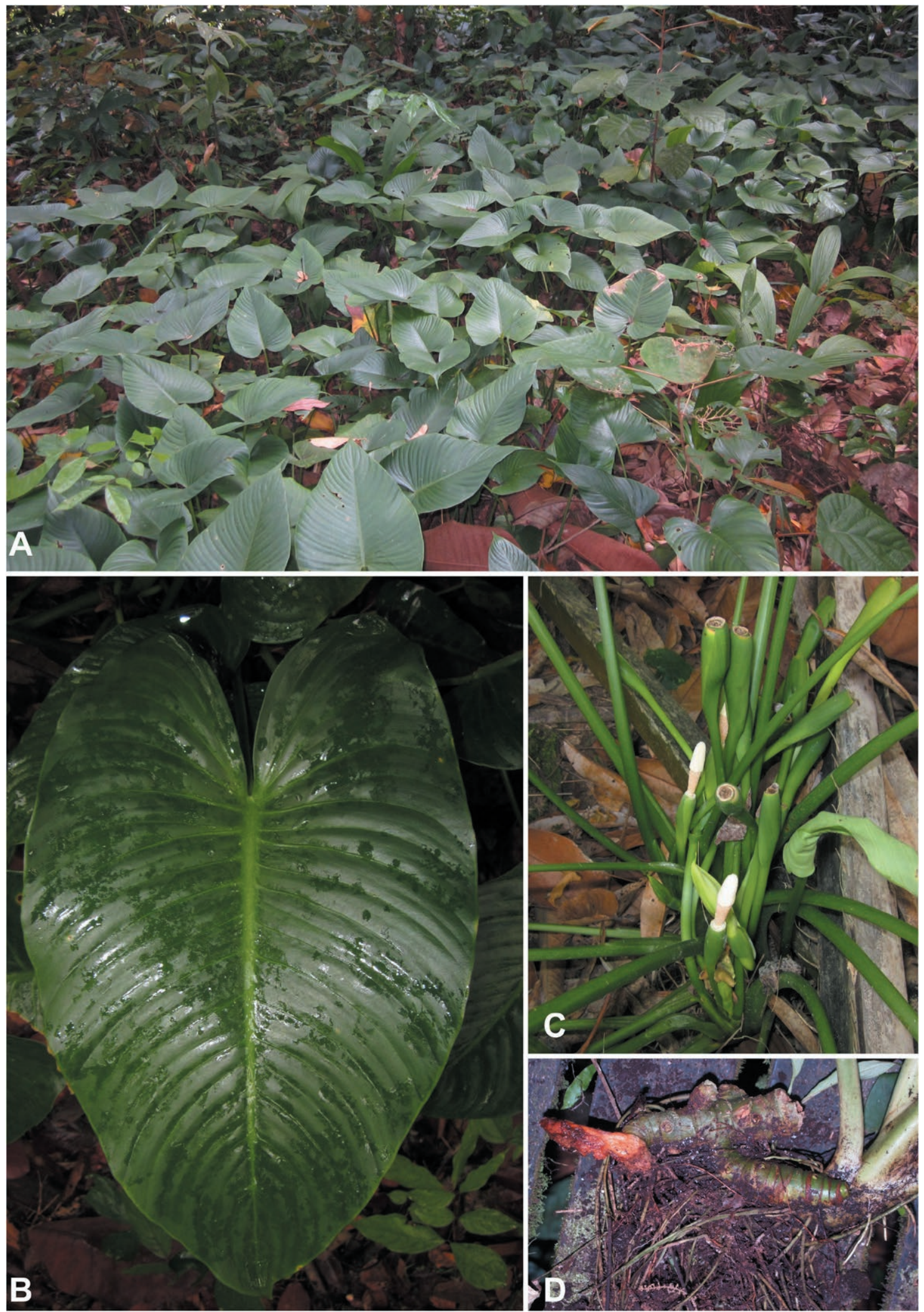

Figure 9. Schismatoglottis niahensis A. Hay. A Plants in habitat. B. Leaf blade, adaxial surface. C. Two flowering shoots showing a succession of blooms. D. Detail of hapaxanthic shoot reiteration. A-D from AR-4666. Images () Hoe Yin Chen. 


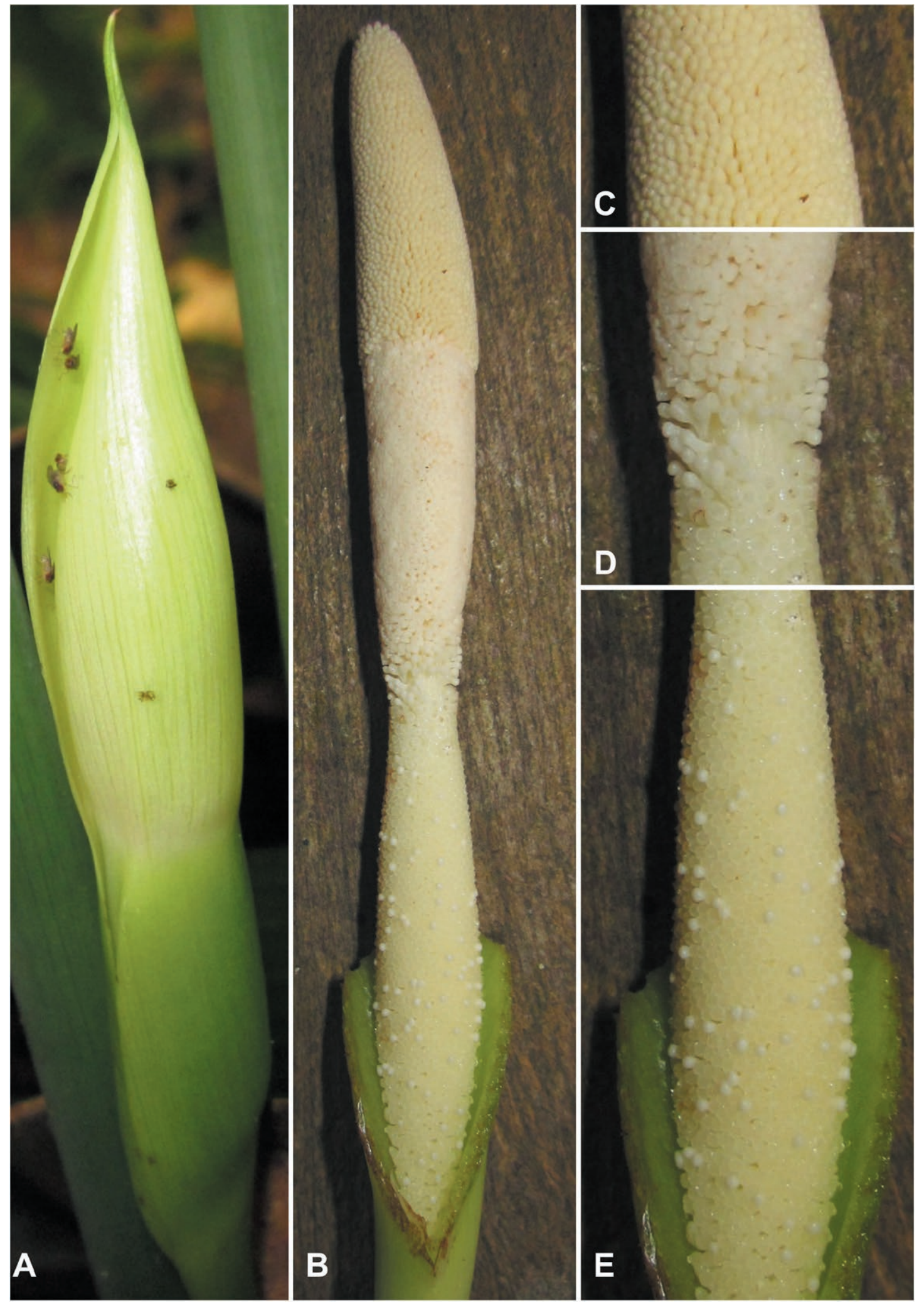

Figure 10. Schismatoglottis niahensis A. Hay. A. Bloom at pistillate anthesis. B. Spadix at pistillate anthesis, spathe artificially removed. C. Detail of spadix, lowermost part of appendix. D. Detail of interstice and uppermost part of pistillate floret zone. E. Detail of pistillate floret zone. A-E from AR-4666. Images (๑) Hoe Yin Chen. 
of the stem epigeal, thus giving a first impression of a pleionanthic shoot. Pollination data presented in Hoe et al. (2018), are under the name "S. pseudoniahensis", a manuscript name we utilized at the time of the study when we had yet to fully understand the identity of the plants occurring at Niah.

\section{Schismatoglottis roh S.Y.Wong, Y.C.Hoe \& P.C.Boyce, sp. nov.}

Type: Malaysian Borneo. Sarawak: Kuching Division, Bau, Krokong, Gua Peri-peri, 1²2’51.9”N 11007'09.3”E, $30 \mathrm{~m}$ asl. 9 May 2009, Wong Sin Yeng \& P.C.Boyce AR-2445 (holotype SAR). (Figures 11, 12 and 14F).

\section{Diagnosis}

Schismatoglottis roh resembles both $S$. baangongensis and S. giamensis by the bullet shaped appendix but is distinguished from both by very densely packed staminate florets, and by the much more abundant pistillate floret staminodes that are each about twice as long as the height of the pistil and truncate-topped (vs at most half as tall again as the pistils and rounded-clavate).

\section{Description}

Moderately robust colonial mesophytic herb, up to $75 \mathrm{~cm}$ tall. Stem hypogeal, hapaxanthic, individual crowns arising from and producing further slender stolons, terminal active portion of stem somewhat epigeal, erect, stolons up to $20 \mathrm{~cm}$ long, internodes 3-10 $\mathrm{cm}$ long, $7-10 \mathrm{~mm}$ in diam. Leaves about 10 per crown; petiole $15-28 \mathrm{~cm}$ long, $2 \mathrm{~cm}$ wide at base, tapering to 5 $\mathrm{mm}$ wide at tip, ventrally broadly channelled for $1 / 4$ of length, smooth, medium green with darker green striations; petiolar sheath 7-11 cm long $\times 5-10 \mathrm{~mm}$ wide, up to $3 / 10$ of petiole length, persistent, fully attached, equal at both sides, slightly in-rolled, tapering; blade 13-25.5 $\times 5-12 \mathrm{~cm}$, narrowly hastato-cordate to rather broadly ovato-cordate, adaxially semi-glossy medium green, posterior lobes broadly triangular, 3-6 cm long, sinus narrow to rather wide, blade apex acute, ultimately tubularmucronate for $1 \mathrm{~cm}$; midrib adaxially slightly impressed, rounded-raised abaxially, $7 \mathrm{~mm}$ wide at the insertion on petiole; primary lateral veins 15 per side, diverging at $40^{\circ}-60^{\circ}$ from midrib, adaxially impressed, rounded raised abaxially alternating with about the same number of interprimary veins, these sometimes arising from near the base of more robust primary veins; secondary veins $0-2$ arising from each primary vein with 3-4 secondary veins arising from primary veins near to petiole insertion; tertiary veins inconspicuous. Blooms up to 6 produced in sequence, erect, very powerfully estericsmelling during anthesis; peduncle $10-25 \mathrm{~cm}$ long $\times 4-9$ $\mathrm{mm}$ wide, terete, dark green with deeper green broken longitudinal lines, erect at anthesis. Spathe 10-12 cm long; lower spathe oblong-ovoid, $4.5 \mathrm{~cm}$ long $\times 1.5 \mathrm{~cm}$ wide, inserted obliquely on peduncle, semi-glossy dark green with darker longitudinal fine striations, demarcated from spathe limb by a pronounced constriction coinciding with start of staminate zone. Spathe $11 \mathrm{~cm}$ long; lower spathe narrowly ovoid, at base strongly dorso-ventrally oblique, $40 \%$ (ventral side) to $25 \%$ (dorsal side) the length of the whole spathe, semi-glossy medium green, smooth; spathe limb at pistillate anthesis much inflated, turbinate, the apex briefly mucronate, completely surrounding the spadix and gaping ventrally, lime green, caducous immediately after pistillate anthesis. Spadix 8 $\mathrm{cm}$ long, about three quarters length of the spathe; pistillate floret zone stoutly fusiform sub-conic, $3 \mathrm{~cm}$ long $\times 8 \mathrm{~mm}$ wide, comprising $50 \%$ of spadix length, creamy white; pistils very densely arranged, sub-globose-cylindric, $1 \mathrm{~mm}$ diam.; style distinct, very short; stigma capitate, somewhat domed, about two thirds the width of the ovary, $0.8 \mathrm{~mm}$ diam.; interpistillar staminodes very numerous, scattered, clavate, about twice as tall as pistils, stipe stout, straight, $3.5 \mathrm{~mm}$ long, pale creamy yellow; sterile interstice very indistinct, slightly narrower than pistillate zone, clothed with a few deformed staminate florets; staminate floret zone stoutly obconic, $3 \mathrm{~cm}$ long $\times 5 \mathrm{~mm}$ wide, about $30 \%$ the length of spadix, creamy white; staminate florets very densely packed with individual florets hardly discernible, $0.5 \mathrm{~mm}$ wide, each comprising 2 truncate stamens, thecae very slightly sunken, surrounded by a narrow rim; appendix bulletshaped, $1.2 \mathrm{~cm}$ long $\times 8 \mathrm{~mm}$ wide, $20 \%$ length of spadix, base wider than the apex of the staminate zone, creamy; staminodes columnar with rounded tops, $2.5 \mathrm{~mm}$ long $\times$ $1 \mathrm{~mm}$ wide. Infructescence on a declinate peduncle, narrowly urceolate, dorsal side of the base strongly oblique, 4-7 cm long $\times 2-2.5 \mathrm{~cm}$ wide, medium green; lower spathe persistent, splitting and reflexing at fruit maturity; fruits $3.5 \mathrm{~mm}$ long $\times 2 \mathrm{~mm}$ wide, ripening semitranslucent white; seeds ovoid ellipsoid, $0.4 \mathrm{~mm}$ diam., longitudinally ridged.

\section{Etymology}

Coined from the Malay language word for a spirit, roh, used by way of allusion to the type locality, Gua Peri-peri, Fairy Cave.

\section{Distribution}

Restricted to Cretaceous Karst in the Bau area of Kuching. 

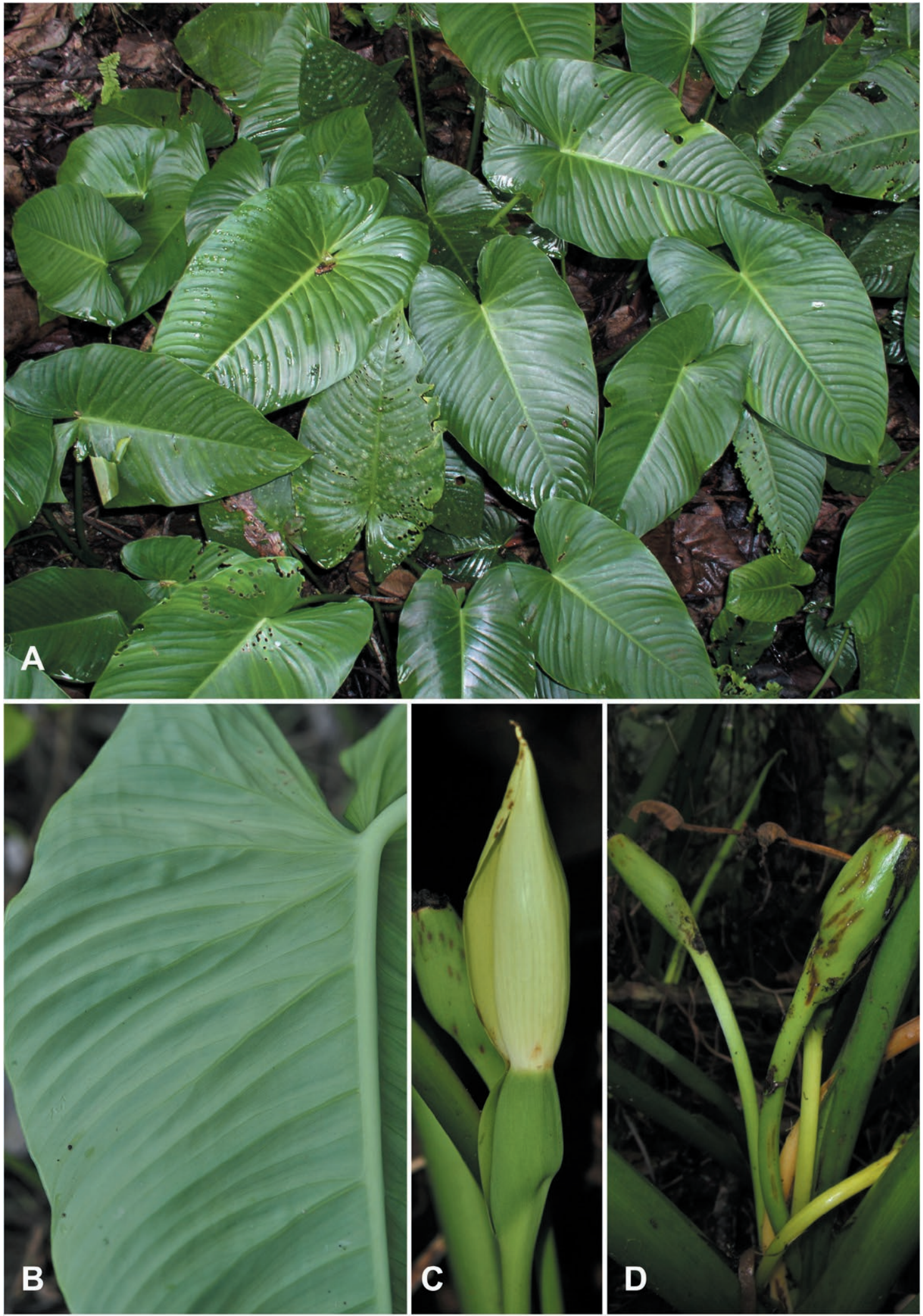

Figure 11. Schismatoglottis roh S. Y. Wong \& P. C. Boyce. A Plants in habitat. B. Leaf blade, abaxial surface. C. Bloom at pistillate anthesis. D. Developing infructescences. A-D from AR-2445. Images @ Hoe Yin Chen. 


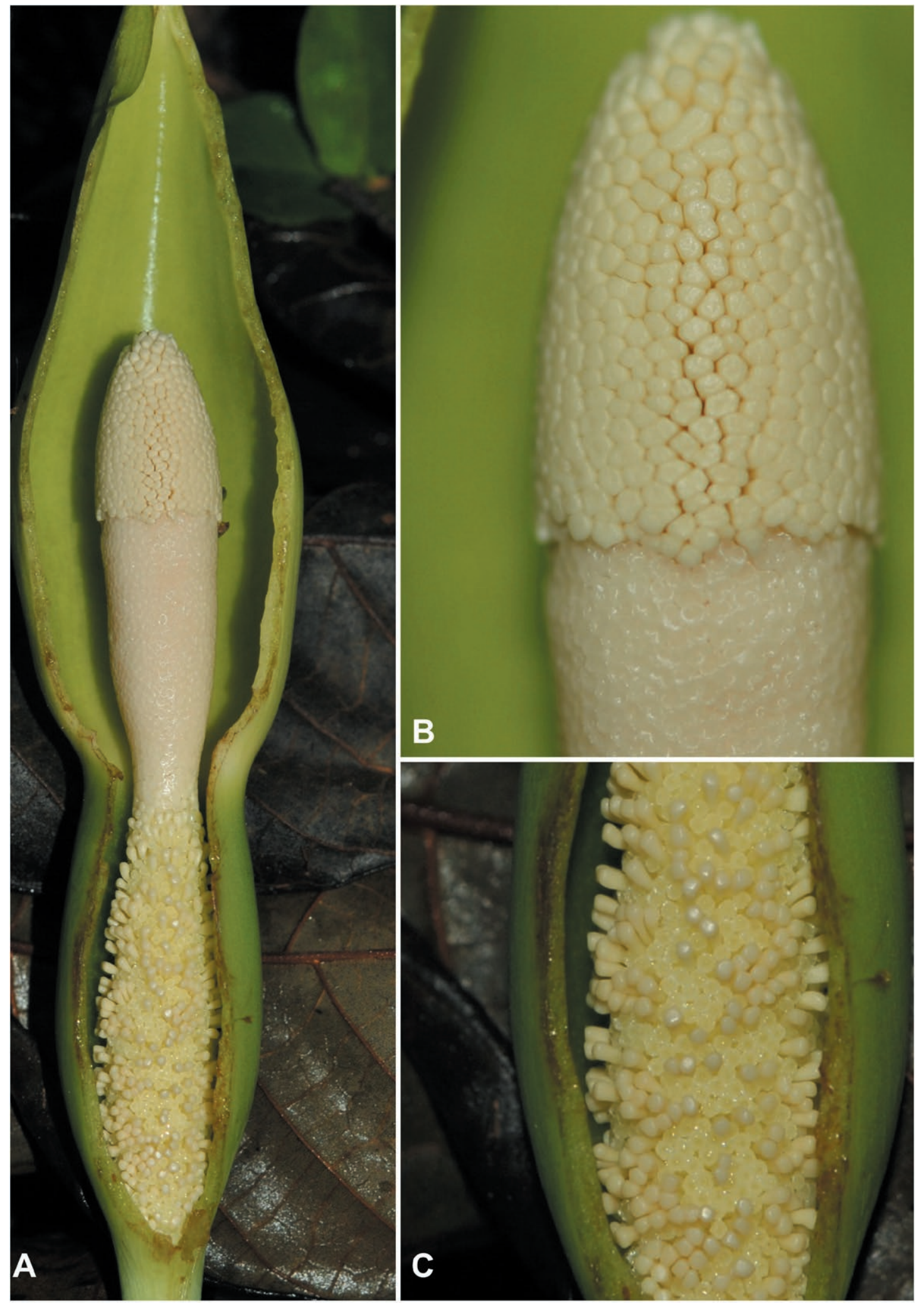

Figure 12. Schismatoglottis roh S. Y. Wong \& P. C. Boyce. A. Bloom at pistillate anthesis, nearside spathe artificially removed. B. Detail of spadix, uppermost portion of staminate floret zone, and appendix. C. Detail of pistillate floret zone. A-E from AR-2445. Images ( $)$ Hoe Yin Chen. 


\section{Ecology}

Occurring in light to medium shade in alluvial soils at the base of Karst stacks, often near to.

\section{Additional specimen examined (paratypes)}

MALAYSIA: Sarawak, Kuching Division. Bau, Gua Angin, $1^{\circ} 24^{\prime} 54.8^{\prime \prime} \mathrm{N} 110^{\circ} 08^{\prime} 08.2^{\prime \prime} \mathrm{E}, 45 \mathrm{~m}$ asl., $21 \mathrm{Jun}$ 2005, P.C.Boyce \& Jeland ak Kisai AR-1240 (SAR). Bau, Jalan Jugan - Siniawan, $1^{\circ} 26^{\prime} 46.97^{\prime \prime N} 110^{\circ} 12^{\prime} 46.88^{\prime \prime}$ E, 15 $\mathrm{m}$ asl., 10 Jun 2016, Wong Sin Yeng \& P.C.Boyce AR-4269 (SAR).

Schismatoglottis viridissima A. Hay, Telopea 9: 154. 2000.

Type: Cult. RBG Sydney Ac No. 940550, C. Herscovitch s.n. ex Malaysian Borneo. Sarawak: Kuching Division, Lundu, Gunung Gading, orig. coll. A.Hay et al. 9397 (holotype SAR!; isotypes K!, KEP!, L!, NSW, US). (Figure 13 and $14 \mathrm{G})$.

\section{Description}

Small mesophytic clump-forming herb to $25 \mathrm{~cm}$ tall. Stem hypogeal, hapaxanthic, $0.5 \mathrm{~cm}$ diam. Leaves 5 together in each crown; petiole to $20 \mathrm{~cm}$ long, sheathing in the lower third; petiolar sheath wings fully attached, tapering but apically truncate; blade narrowly ovate, brilliant green with a rubbery thinly subsucculent texture, $16 \mathrm{~cm}$ long $\times 7 \mathrm{~cm}$ wide, base cordate with rounded posterior lobes to $1.5 \mathrm{~cm}$ long, tip acute; midrib rather prominent; primary lateral veins 7 on each side, irregularly alternating with lesser interprimaries and diverging at $60-80^{\circ}$; secondary venation mostly arising from the midrib, some from bases of primary veins; tertiary venation forming an indistinct tessellate reticulum on both surfaces (visible in dry material). Blooms 2-3 together; peduncle fleshy, $4 \mathrm{~cm}$ long, mostly hidden by sheaths of subtending leaves. Spathe $9 \mathrm{~cm}$ long; lower spathe narrowly ovoid, $4 \mathrm{~cm}$ long, differentiated from limb by an abrupt constriction; limb $5 \mathrm{~cm}$ long, very broadly ovate, inflated over staminate zone and appendix and then acute, finally acuminate for $1 \mathrm{~cm}$, greenish, caducous. Spadix 5-6 cm long, sessile, more or less hourglass-shaped; pistillate flower zone about half the length of spadix, $3 \mathrm{~cm}$ long, adnate to spathe in lower 2/3, $7 \mathrm{~mm}$ diam. in middle, then somewhat conic and attenuate to $5 \mathrm{~mm}$ diam.; pistils somewhat lax, more so in distal part of pistillate zone, bottle-shaped, bright green, $1 \mathrm{~mm}$ diam. in lower part of zone, $2 \mathrm{~mm}$ diam. higher up; interpistillar staminodes scattered among pis- tils, more or less mushroom-shaped, equalling ovaries in height, $0.5 \mathrm{~mm}$ diam.; sterile interstice ill-defined, upper $4 \mathrm{~mm}$ of pistillate zone thickly attenuate and occupied by mixed staminodes, stamens and abortive(?) pistils; staminate flower zone $1.4 \mathrm{~cm}$ long, subcylindric, $5 \mathrm{~mm}$ diam. in lower $5 \mathrm{~mm}$ (held within lower spathe chamber), remainder abruptly obconic, to $9 \mathrm{~mm}$ diam. and exserted from lower spathe chamber; stamens crowded, truncate, hourglass-shaped, with connective thin and not at all elevated above thecae, $1 \mathrm{~mm}$ across; appendix shortly bullet-shaped, base slightly but abruptly wider than top of staminate flower zone, $1 \mathrm{~cm}$ wide at base, $1.3 \mathrm{~cm}$ long; appendix staminodes flat-topped, centrally impressed, irregularly polygonal, $0.5-0.7 \mathrm{~mm}$ diam., dull medium yellow. Fruit unknown.

Etymology

Named for the peculiarly brilliant green leaf blades.

\section{Distribution}

Schismatoglottis viridissima occurs in NW Sarawak and Kalimantan Barat on acidic geologies.

\section{Ecology}

Terrestrial in moderate to light shade under perhumid lowland to upper hill forest on granites, or sandstones; $10-940 \mathrm{~m}$ asl. The Type locality is granite while elsewhere populations of what appears to be the same or at least a remarkably similar species occurs on sandstones (e.g., Kubah N.P, and Gunung Serembu).

\section{Notes}

Hay (Hay \& Yuzammi 2000) erroneously states that S. viridissima occurs on limestone. This most likely is based upon confusion of this species with $S$. roh (see there). A specimen cited by Hay (ibid.) ([J.A.R.]Anderson S.31966) from Bukit Krian in the Bau limestone hills, is a further undescribed species of which currently we lack complete material to enable description.

Key to the colonial and gregarious species of the Schismatoglottis Calyptrata clade in Sarawak

1a. Pistillate zone free; appendix cylindrical, about twice as long a staminate zone; lithophytes of Karst limestone. Mulu N.P. Schismatoglottis muluensis

1b. Pistillate zone dorsally variously adnate to spathe; appendix mostly bullet-shaped, often much shorter than, at most equalling the length of the staminate zone; terrestrial mesophytes, if associated with Karst limestone then never occurring epilithically 

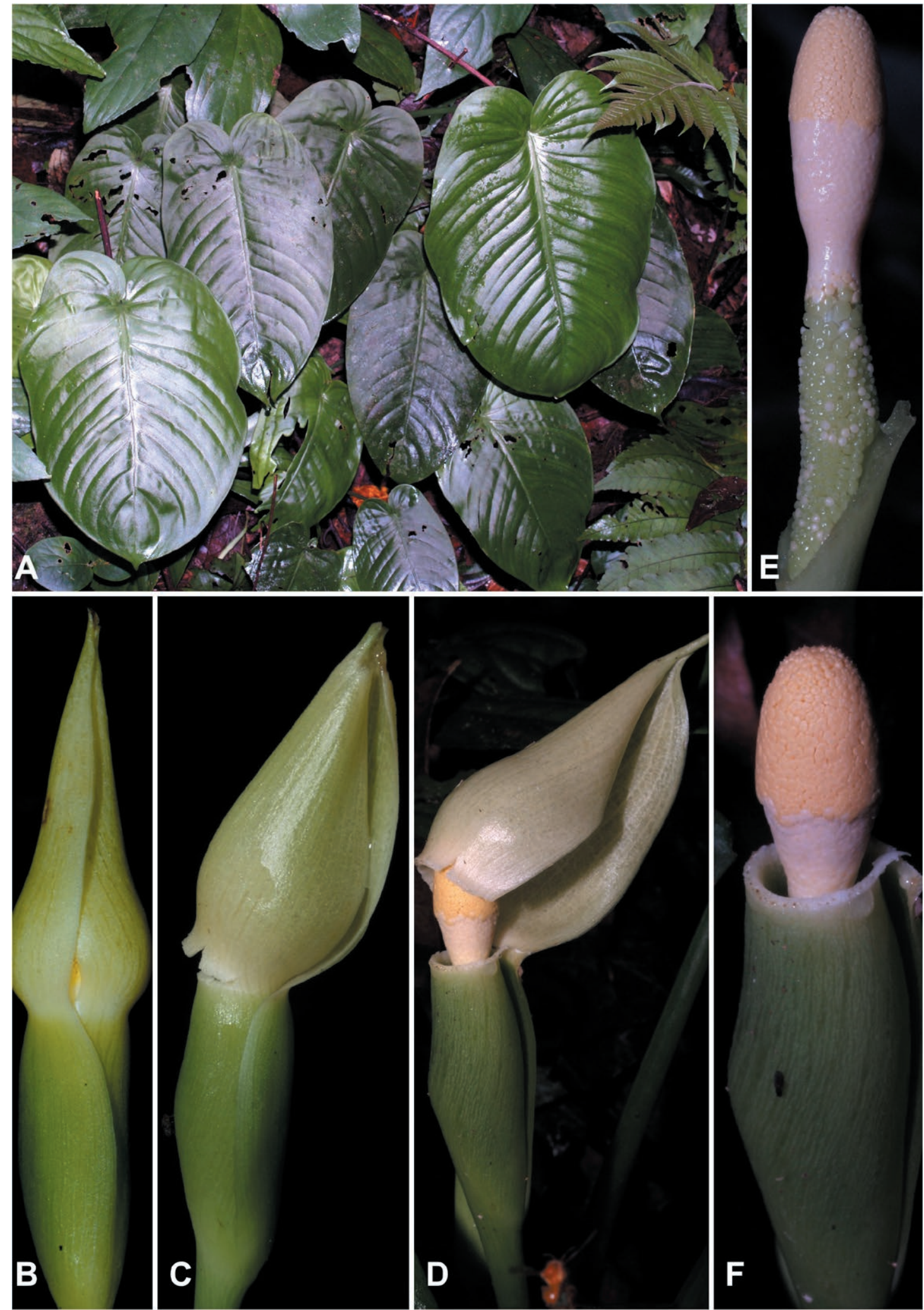

Figure 13. Schismatoglottis viridissima A. Hay. A. Plants in habitat, Gunung Gading N.P. B. Bloom at pistillate anthesis. C. Bloom at onset of staminate anthesis, spathe limb beginning to fall. D. Bloom at late staminate anthesis, spathe limb almost shed. E. Spadix at late pistillate anthesis, spathe artificially removed. F. Bloom post anthesis, spathe limb shed. A-E from AR-5258. Images () P.C. Boyce. 

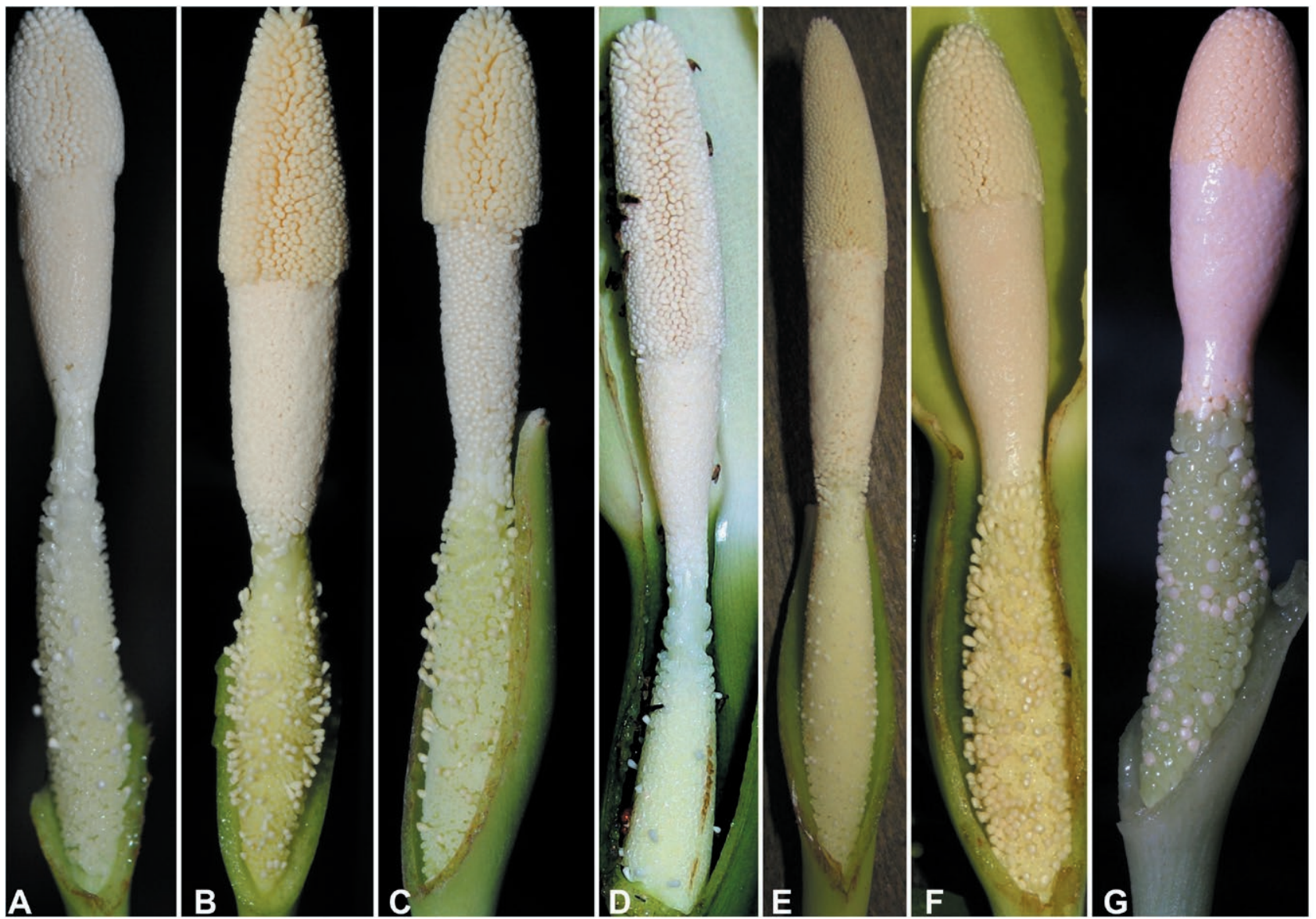

Figure 14. Spadix comparisons. A. Schismatoglottis adducta. B. Schismatoglottis baangongensis. C. Schismatoglottis giamensis. D. Schismatoglottis muluensis. E. Schismatoglottis niahensis. F. Schismatoglottis roh. G. Schismatoglottis viridissima. A from AR-1632. B from AR-2588. C from $A R$-2549. $\mathbf{D}$ from $A R-1941$. $\mathbf{E}$ from $A R-4666 . \mathbf{F}$ from $A R-2445 . \mathbf{G}$ from $A R-5258$. All images $\odot$ P.C. Boyce.

2a. Leaf blades glossy brilliant green, rubbery and sub-succulent; spadix appendix hemispherical; granites and sandstone, Kuching Division Schismatoglottis viridissima

2a. Leaf blades not as above; spadix appendix conical or bullet-shaped

3a. Stems erect and largely epigeal, suckering but not stoloniferous, comprised of greatly elongated hapaxanthic modules. Niah N.P. at the base of Karst cliffs in swampy forest.

Schismatoglottis niahensis

3b. Stems creeping, hypogeal, stoloniferous 4

4a. Staminate and pistillate zones separated by an elongated partially naked interstice; pistillate florets white; interpistillar staminodes few, scattered, all curving-ascending; alluvial forest, Sri Aman.... Schismatoglottis adducta

4b. Staminate and pistillate zones contiguous or nearly so; pistillate florets creamy yellow or pale green; interpistillar staminodes numerous, straight or only very slightly curvingascending. 5a. Staminate florets very densely packed, forming a mass of apparently disorganized stamens, pale creamy yellow; interpistillar staminodes about twice as tall as the height of the pistil, truncate-topped; Cretaceous Karst, Bau.

Schismatoglottis roh

5b. Staminate florets not very densely packed, individuated flowers readily discernible, white; interpistillar staminodes at most half as tall again as the pistils, tops roundedclavate

.. 6

6a. Staminate zone dorsally fully adnate to spathe; thecae with a conspicuous thickened rim; alluvial sandy clay overlying Triassic volcanics.

Schismatoglottis giamensis

6b. Staminate zone dorsally adnate to spathe for about half its length; thecae without a thickend rim; Jurassic Karst limestone.

Schismatoglottis baangongensis 


\section{ACKNOWLEDGEMENTS}

Fieldwork was most recently under Sarawak Forestry Department Permission to Conduct Research on Biological Resources - Permit No. (67) JHS/NCCD/6007/2/107/Jld.2 and Park Permit No WL33/2019. The collaboration and support of the Sarawak Forestry Department and the Sarawak Biodiversity Centre are gratefully acknowledged. The second author extends his thanks to Tan Sri Datuk Amar Leonard Linggi Anak Jugah and Malesiana Tropicals Sdn Bhd for continued support and encouragement.

\section{REFERENCES}

Boyce PC., Wong SY. 2015. Studies on Schismatoglottideae (Araceae) of Borneo L -Schismatoglottis meriraiensis, a new limestone-obligated species with viviparous leaves. Telopea. 18: 443-450.

Hay A. 1996. The genus Schismatoglottis Zoll. \& Moritzi (Araceae: Schismatoglottideae) in Peninsular Malaysia and Singapore. Sandakania. 7: 1-30.

Hay A. 1998. The genus Alocasia (Araceae-Colocasieae) in West Malesia and Sulawesi. Gardens' Bulletin Singapore. 50: 221-334.

Hay A, Yuzammi. 2000. Schismatoglottideae (Araceae) in Malesia I - Schismatoglottis. Telopea. 9: 1-177.

Hoe YC, Wong SY. 2016. Floral biology of Schismatoglottis baangongensis (Araceae) in West Sarawak, Malaysian Borneo. Plant Systematics and Evolution. 302: 1239-1252.

Hoe YC, Gibernau M, Wong SY. 2018. Diversity of pollination ecology in the Schismatoglottis Calyptrata Complex Clade (Araceae). Plant Biology. 20(3): 563-578.

Hotta M. 1966. Notes on Schismatoglottidinae of Borneo. II. Memoirs of the College Science of the University Kyoto, ser.B. 32(3): 223-238.

Huang TC, Hsiao JL, Yeh HY. 2000. Schismatoglottis kotoensis (Hayata) T.C. Huang, J.L.Hsiao \& H.Y.Yeh (Araceae). Taiwania. 45(4): 305-310.

Hutchinson,CS. 1989. Geological Evolution of South-East Asia. Malaysia: Oxford University Press.

Hutchinson, C.S. 2005. Geology of north-west Borneo: Sarawak, Brunei and Sabah. Elsevier, The Netherlands.

Kartini S, Boyce PC, Wong SY. 2015. Studies on Homalomeneae (Araceae) of Borneo XIX: Three new species of geologically obligated Homalomena from Sabah, Malaysian Borneo. Willdenowia. 45: 419-427.

Moritzi, A. 1846. Systematisches Verreichniss der von H. Zollinger in den Jahren 1842-1844 auf Java gesam- melten Pflanzen, nebst einer kurzen Beschreibung der neuen Gattungen und Arten. Solothurn: Irn Verlag des Verfassers, Fr. X. Zepfel.

Tate RB. 2001. The Geology of Borneo Island CD-ROM. Persatuan Geologi Malaysia: Geological Society of Malaysia.

Wong SY. 2012. Studies on Schismatoglottideae (Araceae) of Borneo XXI: Two new species of Schismatoglottis calyptrata Group: Schismatoglottis heterodoxa and Schismatoglottis ranchanensis. Willdenowia. 42: 255260.

Wong SY, Boyce PC. 2020a. Studies on Schismatoglottideae (Araceae) of Peninsular Malaysia II: Schismatoglottis guabatuensis [Calyptrata Clade], a new locally endemic limestone-obligated species. Nordic Journal of Botany. 2020: e02808: 1-5.

Wong SY, Boyce PC. 2020b. Studies on Homalomeneae (Araceae) of Borneo XXIV - Two new geologicallyrestricted species of Homalomena [Chamaecladon clade -Griffithii complex] from NW Borneo. Annales Botanici Fennici. 57: 285-292.

Wong SY, Hay A, Boyce PC. 2018. An annotated checklist for Schismatoglottis. Aroideana. 41(2-3): 34-200.

Wong SY, Hoe YC, Boyce PC. 2016. Studies on Schismatoglottideae (Araceae) of Borneo LIX - A preliminary conspectus of Schismatoglottis Calyptrata Clade species for Sarawak. Aroideana. 39(2): 71-100. 